\title{
Burdens of Proof
}

\section{Photography and Evidence of Atrocity during the Dutch Military Actions in Indonesia (1945-1950)}

\author{
Susie Protschky \\ Monash University, Clayton, Australia \\ susanne.protschky@monash.edu
}

\begin{abstract}
There is but a limited scholarship on photographic sources from the Dutch military actions during the Revolusi Nasional Indonesia (Indonesian National Revolution) (1945-1949), and what exists almost entirely neglects perhaps the largest component of the archives: Dutch soldiers' amateur photographs. Yet this category of photographs has simultaneously attracted much public and media controversy. This article contends that a narrow range of soldiers' amateur photographs have thus far borne an anomalously weighty burden of proof to substantiate the nature and limits of extreme violence during the National Revolution, one that is brittle and difficult to sustain unless historians begin to broaden the focus of investigations into photographic archives. This article also investigates what it may mean for present-day Indonesians to see their ancestors as perpetrators as well as victims of violence and, importantly, as occupants of the ambiguous categories between both ends of this spectrum. What are the ethics of looking at and reproducing these photographs, and to whom do they belong?
\end{abstract}

\section{Keywords}

Revolusi Nasional Indonesia (Indonesian National Revolution) - Dutch military operations in Indonesia, 1945-1949 - photography - violence - decolonization

In July 2012, a major Dutch news outlet, de Volkskrant, published a story that purported to show, 'for the first time in history', two photographs of atrocities committed by Dutch soldiers during the Indonesian War of Independence. ${ }^{1}$

1 Translations from Dutch throughout this article are my own. Lidy Nicolasen, 'Eerste foto's ooit 
One image (hereafter, 'the first Jacobus $\mathrm{R}$ photograph') captures the moment when three Indonesians, lined up in a ditch with their backs to the viewer, are facing dust raised by bullets fired from outside the frame. A second photograph shows a ditch, perhaps the same one from a different angle, now filled with the bodies of Indonesians. Uniformed Dutch soldiers are standing next to it. Together, the photographs appear to document the moments during and after an execution.

The news article revealed the origin of these two photographs as the private album of 'Jacobus R', ' a Dutch soldier who had served in an artillery division of the Koninklijke Landmacht (Royal Army) during both major counterinsurgencies launched by Dutch forces against Indonesian militias, from 21 July to 5 August 1947 and 19 December 1948 to 5 January $1949 .{ }^{3}$ These two images, henceforth the 'Jacobus R photographs', have since been republished in Dutch news media outlets at least seventeen times, ${ }^{4}$ as well as in Indonesian news

van executies Nederlands leger in Indië', de Volkskrant, 10-7-2012. http://www.volkskrant.nl/ binnenland/eerste-foto-s-ooit-van-executies-nederlands-leger-in-indie a3284391/. In a follow-up article, Nicolasen says: 'this is the first time in history that visual material has been found': Laura de Jong en Marjan van den Berg, 'Opgedoken executiefoto's: "Het was dus echt een oorlog"', de Volkskrant, 10-7-2012. http://www.volkskrant.nl/magazine/opgedoken -executiefoto-s-het-was-dus-echt-een-oorlog a3284455/.

2 His surname was Ridderhof. Albums held at the Stadsarchief Enschede (Enschede Municipal Archives).

3 The official names of the campaigns were 'Operatie Product' (Operation Product) and 'Operatie Kraai' (Operation Crow), known in Dutch historiography as the First and Second 'police actions', and in Indonesian histories as 'military aggressions'.

4 Here I cite digital publications only: Laura de Jong en Marjan van den Berg, 'Opgedoken executiefoto's: "Het was dus echt een oorlog"', de Volkskrant, 10-7-2012. http://www.volkskrant.nl/ magazine/opgedoken-executiefoto-s-het-was-dus-echt-een-oorlog a3284455/;'Foto's gevonden van executies in Indië door Nederlands leger', Trouw, 10-7-2012. http://www.trouw.nl/ $\operatorname{tr} / \mathrm{nl} / 4492 /$ Nederland/article/detail/3284399/2012/07/10/Foto-s-gevonden-van-executies-in -Indie-door-Nederlands-leger.dhtml; 'Foto's gevonden van executies in Indië door Nederlands leger', Algemeen Dagblad, 10-7-2012. http://www.ad.nl/binnenland/foto-s-gevonden-vanexecuties-in-indie-door-nederlands-leger a8cc2e54/; Lex Boon, 'Vijfenzestig jaar na dato: Foto's van Nederlandse executies in Indië', NRC Handelsblad, 10-7-2012. https://www.nrc.nl/ nieuws/2012/o7/10/vijfenzestig-jaar-na-dato-fotos-van-executies-in-nederlands-indie-a1443 369; Marije Willems, 'Eerste beelden executies Nederlands-Indië opgedoken', NRC Handelsblad, 10-7-2012. https://www.nrc.nl/nieuws/2012/o7/10/eerste-beelden-executies-in-voorma lig-nederlands-indie-opgedoken-a1443379; Laura de Jong, 'Dat Nederlanders als beesten tekeer zijn gegaan, wordt er hier met de paplepel ingegoten', de Volkskrant, 11-7-2012. http:// www.volkskrant.nl/magazine/-dat-nederlanders-als-beesten-tekeer-zijn-gegaan-wordt-er -hier-met-de-paplepel-ingegoten a3285103/; Dirk Wijnand de Jong, 'Nederlandse regering niet van plan geweld in Indië te onderzoeken', NRC Handelsblad, 15-8-2012. https://www.nrc .nl/nieuws/2012/o8/15/nederlandse-regering-niet-van-plan-geweld-indie-te-onderzoeken -a1442452; 'Veteraan herkent zichzelf op executiefoto's Nederlands-Indië', de Volkskrant, 
sources and social media. The organization that originally published the photographs ranked them as its second most frequently viewed set of images for the year. ${ }^{5}$

One photograph depicts the execution itself; or perhaps it was a split-second-before, 'about to die' photograph (Zelizer 2010), where the outcome seems fairly certain. The visceral shock of this uncannily timed photograph derives from the blur of movement it captures, which, rather than detracting from the image, brings to life the moment of the three men's deaths. In this regard, the photograph resonates with iconic portraits in the execution genre from other twentieth-century conflicts in Southeast Asia, notably Edward T. (Eddie) Adams's Pulitzer Prize-winning photograph of General Nguyễn Ngọc Loan shooting Vietcong prisoner Nguyễn Văn Lém in Saigon in February $1968 .{ }^{6}$ Indeed, scholars have recently characterized the Indonesian War of Independence as 'the Dutch Vietnam,'7 a protracted Dutch war of counter-insurgency against Indonesian guerrilla as well as conventional forces, which were united in their opposition to colonial rule but divided among themselves over the form of the postcolonial nation they envisaged. The illustrative drama of the first Jacobus R photograph, the likes of which specialists at two major cus-

13-7-2013. http://www.volkskrant.nl/binnenland/-veteraan-herkent-zichzelf-op-executiefoto -s-nederlands-indie a3475288/; 'Nederlandse excuses voor executies Indië', de Volkskrant, 11-9-2013. http://www.volkskrant.nl/buitenland/nederlandse-excuses-voor-executies-indie a3507971/; 'Commandant bekent executies Indië na dood', Algemeen Dagblad, 19-9-2013. http://www.ad.nl/binnenland/commandant-bekent-executies-indie-na-dood are34968/;

'Nederland maakt excuses voor executies Indonesië', Algemeen Dagblad, 12-9-2013. http:// www.ad.nl/binnenland/nederland-maakt-excuses-voor-executies-indonesie ad8o2263/;

'Vergoeding voor zeven weduwen Zuid-Sulawesi', Trouw, 29-7-2014. https://www.trouw.nl/ home/vergoeding-voor-zeven-weduwen-zuid-sulawesi ac81ad81/; Natalie Righton, 'Kabinet akkoord met groot onderzoek naar geweld Indië', de Volkskrant, 2-12-2016. http://www.volks krant.nl/binnenland/kabinet-akkoord-met-groot-onderzoek-naar-geweld-indie a a426593/; Bastiaan Nagtegaal, 'Hof: Het geweld van militairen in Nederlands-Indië uit 1947 niet verjaard', $N R C$, 1-10-2019. https://www.nrc.nl/nieuws/2019/10/o1/hof-geweld-van-militairen-in -nederlands-indie-uit-1947-niet-verjaard-a3975179.

5 'Van Nederlands-Indië naar de maan: De best bekeken fotoreeksen van dit jaar', de Volkskrant, 25-12-2012. http://www.volkskrant.nl/binnenland/van-nederlands-indie-naar-de-maan-de-b est-bekeken-fotoreeksen-van-dit-jaar a3367103/.

6 The photograph, which won the 1969 Pulitzer Prize for 'Spot News Photography', was titled 'Saigon execution', and can be viewed at https://en.wikipedia.org/wiki/Eddie_Adams_(photo grapher)\#/media/File:Nguyen.jpg. For a discussion of the historical and cultural impact of the photograph, see Hagopian 2006:209-13 and Brothers 1997:203-4.

7 Bart Luttikhuis and Gerda Jansen Hendriks, 'Ons Indië een tweede Vietnam?', NPO Radio 1, 7-12-14. http://www.nporadio1.nl/ovt/onderwerpen/246oo7-ons-indie-een-tweede-vietnam (accessed 26-05-2020); Limpach 2016:323. 
todial institutions in the Netherlands went on record to attest to not having seen before, ${ }^{8}$ perhaps explains its longer cycle of reproduction in the Dutch news media, in scholarly works (it has been discussed or reproduced in almost every academic work on the Indonesian War of Independence published since 2012), ${ }^{9}$ and in a recent, important, and very comprehensive photo exhibition on colonial war at the Verzetsmuseum (Resistance Museum) in Amsterdam. ${ }^{10}$ Indeed, the image has arguably come to stand for all the Dutch atrocities committed during what is increasingly being seen by historians as an inglorious war.

Before 2012, media reports on Dutch atrocities committed during the Indonesian War of Independence were gaining public prominence in the lead-up to a civil case brought against the Dutch government on behalf of the widows of victims summarily executed by Dutch soldiers in the West Javanese village of Rawagedeh in 1947. In 2013 the women were awarded compensation and extended a formal apology by the Dutch government, with further apologies for other massacres to follow (Luttikhuis 2014; McGregor 2014). At this time, news media reports on these matters were rarely, if ever, accompanied by photographs made during the war, let alone by images that might substantiate atrocities. To that extent, the Jacobus R photographs published in July 2012 were indeed unprecedented.

They were followed by more examples. In 2013, a Dutch news outlet published a photograph that showed Indonesian bodies in a field outside a village." In 2015, a fourth photograph circulated in the news media that showed six dead men lying in a ditch. Three were naked from the waist down, and their strawcovered genitals suggest a hasty cover-up. ${ }^{12}$ In his major, significant book on the war, historian Rémy Limpach (2016: plate 74) reproduces another photo-

8 Lidy Nicolasen, 'Eerste foto's ooit van executies Nederlands leger in Indië', de Volkskrant, 10-7-2012. http://www.volkskrant.nl/binnenland/eerste-foto-s-ooit-van-executies -nederlands-leger-in-indie $23284391 /$. The experts cited were specifically referring to execution photographs.

$9 \quad$ The photograph is discussed in Zweers 2014:12 and reproduced in Luttikhuis and Moses 2014:3; Lorenz 2015; and Limpach 2016: plates 64 and 65.

10 Koloniale oorlog 1945-1949: Gewenst beeld; ongewenst beeld (Verzetsmuseum Amsterdam, 26 November 2015-3 April 2016); see also the exhibition guide (Kok, Somers and Zweers 2015:214-5).

11 Meindert van der Kaaij, 'Verzetsheld verantwoordelijk voor bloedbaden in Indië', Trouw, 12-9-2013. http://www.trouw.nl/tr/nl/4324/Nieuws/article/detail/3508035/2013/og/12/Ver zetsheld-verantwoordelijk-voor-bloedbaden-in-Indie.dhtml.

12 Lidy Nicolasen, 'Nieuwe executiefoto's Nederlands-Indië opgedoken', de Volkskrant, 16-102015. http://www.volkskrant.nl/buitenland/nieuwe-executiefoto-s-nederlands-indie -opgedoken a4164141/. 
graph that shows Dutch soldiers taking prisoners who were made to expose their genitals at gunpoint. He suggests this strategy was employed by Dutch soldiers to terrorize prisoners, an interpretation that resonates with present-day audiences familiar with the photographs taken by American soldiers at Abu Ghraib prison during the war in Iraq (Smith 2013). Both of these photographs of executed prisoners have subsequently been republished elsewhere. ${ }^{13}$

With the notable exception of the first Jacobus R photograph, most iterations of what we might term photographs in the 'execution genre' focus on the aftermath of mass killings perpetrated by Dutch soldiers. They record the bodies of recently slain Indonesian men that were collected by Dutch armed forces in preparation for disposal or burial. These photographs take their place within a longer history of colonial military violence in Indonesia that, as Paul $\mathrm{Bijl}(2015 \mathrm{~b})$ has shown, was already familiar to colonial audiences in the Netherlands and its then colony, the Netherlands East Indies, long before the conflict of the late 1940s. Thematically similar photographs - of rivers of bodies overseen by their killers, colonial soldiers-were publicized shortly after the Dutch subjugation of the Gayo and Alas lands in 1904, which brought the Aceh War to a formal close. ${ }^{14}$

That there is a genealogy to the broader genre of colonial execution photographs has not tempered the media discourse of novelty around the two Jacobus R photographs, in particular, the claims that such images have never been seen before and are evidence of Dutch atrocities that were formerly invisible to the public. News reports have also focused on revelations of how the photographs from this conflict were found. The Jacobus R photographs, for example, were fortuitously discovered in a rubbish container by an employee of the city

13 The 2013 photograph was published in Kester Freriks, 'Een vuile oorlog, en veel vuile leugens', NRC Handelsblad, 19-8-2016. https://www.nrc.nl/nieuws/2016/o8/19/een-vuile -oorlog-en-veel-vuile-leugens-369o834-a1516989, and Limpach 2016: plate 38. The 2015 photograph was published in René Kok, Erik Somers en Louis Zweers, 'Foto toont geen hard bewijs voor executies', de Volkskrant, 20-10-2015. http://www.volkskrant.nl/opinie/ foto-toont-geen-hard-bewijs-voor-executies a4166635/; Kok, Somers and Zweers 2015:47; Natalie Righton, 'Kabinet akkoord met groot onderzoek naar geweld Indië', de Volkskrant, 2-12-2016. http://www.volkskrant.nl/binnenland/kabinet-akkoord-met-groot-onderzoek -naar-geweld-indie a4426593/; Limpach 2016: plate 66.

14 See the collection of the Nationaal Museum van Wereldculturen (National Museum of World Cultures): TM-6ooo1244 (1904). http://collectie.wereldculturen.nl/Default.aspx ?ccid=208854\&lang= (accessed 26-05-2020); TM-6oo11258 (1904). http://collectie.wereldc ulturen.nl/Default.aspx?ccid=307826\&lang $=($ accessed $26-05-2020)$. These photographs (and others taken during this campaign) are the subject of Bijl 2015b. On the continuities with colonial violence perpetrated by the KNIL, in Aceh and elsewhere, see Kreike 2014; Oostindie, Hoogenboom and Verwey 2015:32. 
archives in Enschede. ${ }^{15}$ The 2015 photograph of the half-naked bodies covered with straw was found in the vault of a former bank building in Gouda, now the Verzetsmuseum (Resistance Museum) of South Holland. An archivist discovered the photograph by accident, among a cache of Bronnley's soap boxes filled with archive material from the Second World War. ${ }^{16}$ The discovery narrative around these photographs, rescued from obscurity among the detritus of regional museums, figures historical research on colonial violence as inadvertent detective work, or perhaps, less edifyingly, as accidental archaeology. Stories of the chance and precarious retrieval of atrocity photographs perpetuates the notion that extreme violence has been invisible in the historical record up until now; that the past these objects emerge from is generally opaque and secret; and that the violence they document is exceptional, without precedent in the history of Dutch colonial rule (Bijl 2014; Lorenz 2015). When the form of contrary evidence is photographic, it is called upon to serve as incontrovertible truth that enables public 'witnessing' - so crucial to contemporary discourses of rights and restitution —of events that were murky or unverifiable beforehand (Azoulay 2011; Kennedy and Patrick 2014:2-3).

As historians have repeatedly demonstrated, however, claims of atrocities perpetrated by Dutch soldiers against Indonesian civilians and prisoners of war were frequently known to the high command during the military actions of 1945-1950 and have persistently circulated in the public sphere since at least 1969, when Dutch veteran Joop Hueting gave a televised interview in which he confessed to having witnessed atrocities, thereby prompting the first Dutch government investigation into military 'excesses'. Recent studies substantiate the extent to which ordinary soldiers and the Dutch high command were implicated in acts that can be considered structural and systematic extreme violence (Oostindie, Hoogenboom and Verwey 2015; Limpach 2016). There is also a burgeoning critical historiography of the postcolonial memory politics surrounding the extent and nature of extreme violence perpetrated by Dutch soldiers. ${ }^{17}$

Given, firstly, the growing momentum for revising Dutch actions in the Indonesian War of Independence, which has been legitimized by the latest

\footnotetext{
15 Lidy Nicolasen, 'Eerste foto's ooit van executies Nederlands leger in Indië', de Volkskrant, 10-7-2012. http://www.volkskrant.nl/binnenland/eerste-foto-s-ooit-van-executies -nederlands-leger-in-indie a3284391/.

16 Lidy Nicolasen, 'Nieuwe executiefoto's Nederlands-Indië opgedoken', de Volkskrant, 16-102015. http://www.volkskrant.nl/buitenland/nieuwe-executiefoto-s-nederlands-indie -opgedoken a4164141/.

17 Scagliola 2014; Van Ooijen and Raaijmakers 2014; Bijl 2014; Lorenz 2015.
} 
Dutch government initiative to support a wide-ranging, independent inquiry into the conflict, and secondly, the widespread media circulation of execution photographs from the conflict, there has, to date, been a striking dearth of analysis of the role that Dutch soldiers' amateur photographs might play in historical revisions of extreme violence in this conflict. With the notable exception of the book accompanying the 2015/16 exhibition on colonial war in Amsterdam (Kok, Somers and Zweers 2015), what exists has focused on the genres of photo journalism and propaganda or intelligence photography, especially previously unseen visual reportage (Zweers 2014). However, while journalists were often 'embedded' in Dutch military and intelligence organizations, and therefore shared conditions with 'ordinary' soldiers (Zweers 2014:236-67; Kok, Somers and Zweers 2015:52, 64, 67, 183), the audiences and intended uses of amateur soldiers' photographs differed from those of press and official photographers in ways that impinge on the content and meaning of these two related, but ultimately distinct, genres of photography. Most importantly, soldiers' amateur snaps, like the Jacobus $\mathrm{R}$ photographs, were never intended for the public audiences among which they circulate today. Yet the media distribution of these photographs has arguably set the parameters for debatesmostly Dutch initially, but now international—on what the public can and should know about how the Netherlands fought its last colonial war in Indonesia, and on how this knowledge can be acquired. Written ego documents and official archives will no doubt continue to play the most significant part in historical revisions of the Dutch military actions in Indonesia. However, photographs have been, and will likely continue to be, used to illustrate works on the conflict. Where visual sources are concerned, I contend that the Jacobus R photographs and their ilk have thus far borne an anomalously weighty burden of proof to substantiate the nature and limits of extreme violence in the conflict, one that is brittle and difficult to sustain unless we begin to broaden the focus of historical investigations into this colonial photographic archive.

Almost immediately, the burden of proof assigned to the Jacobus $\mathrm{R}$ photographs in press reports - of tendering evidence of atrocities committed by Dutch soldiers against Indonesians - was contested by key 'stakeholders', notably, former soldiers themselves. Leen Noordzij, the president of a veteran's association in the Netherlands (the Vereniging Oud-Militairen Indiëgangers, or vomI), had an opinion piece published by a news outlet in which he insisted 
that it would be very difficult to establish from these photographs alone that an atrocity had been committed. 'There appear to be two Dutch soldiers in the photo', Noordzij admitted, 'but that is not proof that they also murdered the civilians. They [the soldiers] could also, for example, have confronted them [the civilians] while on patrol. [...] Without a context for the photos it is not appropriate to draw conclusions. ${ }^{18}$

That we are indeed looking at an execution has since been verified by a veteran who came forward after having 'recognized himself' and a fellow soldier as the two Dutch figures in the second Jacobus R photograph. ${ }^{19}$ This confession prompted revelations in news outlets from other soldiers who admitted to having witnessed, or participated in, similar executions. ${ }^{20}$ Putting aside for the moment the verification of the photographs as showing what they were purported by the media to reveal—and putting aside Noordzij's motive of defending the honour of his constituents, bolstered by a strategy of defaming contrary narratives (he claims that careerist self-interest underpinned historians' reasons for revisiting the question of Dutch atrocities in the war) - the author's doubts that the photographs attested 'with certainty' to 'executions carried out by Dutch soldiers'21 address important concerns. 'The photograph is merely one of the components through which one can restore the atrocity that took place "there", where it was taken', the renowned theorist Ariella Azoulay concurs, 'but in order for it to be regarded as an atrocity, the photograph does not suffice' (2012:252). Doubts about, and denial of, the violence evoked in amateur (and sometimes unknown) soldiers' photographs have two implications for the burdens of proof that images are vested with in debates about extreme violence in the war. The first has to do with the nature of photographs as historical evidence per se. The second concerns the historical questions we ask of photographs, and the political work they are made to perform as post/colonial archives.

18 Leen Noordzij, 'Indië-veteraan is weer snel veroordeeld', Trouw, 15-7-2012. https://www .trouw.nl/opinie/indie-veteraan-is-weer-snel-veroordeeld af58ac9a/ (accessed 26-o52020).

19 'Veteraan herkent zichzelf op executiefoto's Nederlands-Indië', de Volkskrant, 13-7-2013. http://www.volkskrant.nl/binnenland/-veteraan-herkent-zichzelf-op-executiefoto-s -nederlands-indie a $3475288 /$. We now know that the Jacobus R photographs were taken in March 1949 in South Sumatra.

20 'Commandant bekent executies Indië na dood', Algemeen Dagblad, 19-9-2013. http://www .ad.nl/binnenland/commandant-bekent-executies-indie-na-dood a1e34968/.

21 Leen Noordzij, 'Indië-veteraan is weer snel veroordeeld', Trouw, 15-7-2012. https://www .trouw.nl/opinie/indie-veteraan-is-weer-snel-veroordeeld af58acga/ (accessed 26-05-20 20). 
To begin with the first implication, the difficulty of extrapolating agents, causes, motives, and other complex relations and narratives from photographs alone is a quality that historians of photography have long acknowledged and do not dispute. Particularly relevant are debates about the 'indexicality' of photographs: the extent to which images, made using light and chemical processes to print the trace of an object onto a surface, can be said to correspond exactly to that which they signify. While theorists have elaborated on the many ways in which photographs routinely defy expectations of indexicality, particularly by exceeding the intensions of their makers as they address different audiences over space and time, ${ }^{22}$ the common exception to this argument that often arises is the atrocity photograph: the photograph that is made to bear witness or testify to extreme violence (Azoulay 2012; Prosser 2012; Lowe 2014). The status of such documentary photographs typically, and chiefly, derives from the assumption and invocation of their indexicality.

As Noordzij demonstrated, there are strategies for undermining such assumptions. For instance, in his piece he suggested that the Jacobus $\mathrm{R}$ photographs need not be showing acts of impunity, that is, extra-judicial executions of prisoners of war, which would constitute war crimes. ${ }^{23}$ They may instead have shown killings that are legally permitted in wartime. His argumentation turns on juridical definitions of atrocity, which have recently gained enormous purchase in the Netherlands. The Dutch government has been subject to a growing number of cases prosecuted in the domestic civil courts by Indonesian claimants seeking financial compensation and formal apologies. ${ }^{24}$ As historian Bart Luttikhuis (2014) persuasively argues, these 'legally sanctioned apologies' have restored some agency and justice to Indonesian victims of atrocity, but at the cost of the moral element that accompanies voluntary apologies. Further,

22 Barthes 2010 [1980]:32, 100; Edwards 2001:5, 6, 12, 187, 192-3; Morton and Edwards 2009:7; Pinney 2003:6.

23 According to the 1929 Geneva Convention that the Dutch authorities were ostensibly bound to; see Luttikhuis 2018 .

24 'Nederlandse excuses voor executies Indië', de Volkskrant, 11-9-2013. http://www.volkskrant .nl/buitenland/nederlandse-excuses-voor-executies-indie a3507971/; Sterre van der Hee, 'Nederlandse Staat aansprakelijk gesteld voor verkrachting Indië', NRC Handelsblad, 27-12016. https://www.nrc.nl/nieuws/2016/o1/27/nederlandse-staat-aansprakelijk-gesteld-vo or-verkrachting-indie-a1409810 (accessed 26-o5-2020); Lidy Nicolasen, 'Waterboarding gebeurde ook in Nederlands-Indië', de Volkskrant, 11-12-2014. http://www.volkskrant.nl/ binnenland/-waterboarding-gebeurde-ook-in-nederlands-indie a38og263/ (accessed 2605-2020); Daniel Boffey, 'Relatives of Dutch colonial victims in Indonesia to get day in court', The Guardian, 2-10-2019. https://www.theguardian.com/world/2019/oct/o1/relative s-of-dutch-colonial-victims-in-indonesia-to-get-day-in-court (accessed 26-o5-2020). 
the narrowly judicial scope of inquiries into extreme violence limits understandings of Dutch as well as Indonesian actions in the war.

The public attention focused through mainstream Dutch media on a small number of execution photographs burdened with the task of proving certain types of atrocity seems to be drawing the use of photographic sources towards a similarly finite debate about the nature and extent of extreme violence in the Indonesian War of Independence. ${ }^{25}$ Within this narrow framework, the exceptional status of execution photographs in the postcolonial archive is emphasized by their ostensive contrast to the larger body of other, comparatively innocuous pictures that soldiers took during their service. As Noordzij pointed out in his critique of the Jacobus R photographs, "[m]ost of the photos in the album [...] are actually nothing out of the ordinary'. ${ }^{\prime 2} \mathrm{He}$ is right, especially given the longer history of amateur war photography (Struk 2011), but I contest his separate point that there is nothing further to see in this particular archive of photographs.

After the story of the Jacobus R photographs had broken, numerous news outlets published an image of the album open on the page where the two famous photographs were found. ${ }^{27}$ Viewed from left to right, top to bottom, the

25 Apart from mainstream Dutch news outlets, the critical commentary of the group Histori Bersama (Shared History) is notable for mainly (although not always) operating through social rather than traditional media. See https://www.facebook.com/historibersama, historibersama.com, and @HistoriBersama.

26 Leen Noordzij, 'Indië-veteraan is weer snel veroordeeld', Trouw, 15-7-2012. https://www .trouw.nl/opinie/indie-veteraan-is-weer-snel-veroordeeld af58acga/ (accessed 26-o5-2O 20).

27 'Indië-weigeraars vragen heropening strafzaak', Algemeen Dagblad, 15-12-2012. http://www .ad.nl/buitenland/indie-weigeraars-vragen-heropening-strafzaak aarb98c6/ (accessed 26 -05-2020); 'Indië-weigeraars vragen heropening strafzaak', Trouw, 15-12-2012. http://www .trouw.nl/tr/nl/4324/Nieuws/article/detail/3364018/2012/12/15/Indie-weigeraars-vragenheropening-strafzaak.dhtml (accessed 26-05-2020); 'Van Nederlands-Indië naar de maan: De best bekeken fotoreeksen van dit jaar', de Volkskrant, 25-12-2012. http://www.volkskrant .nl/binnenland/van-nederlands-indie-naar-de-maan-de-best-bekeken-fotoreeksen-vandit-jaar a3367103/; 'Indië-weigeraars vragen heropening strafzaak', de Volkskrant, 15-122012 http://www.volkskrant.nl/politiek/indie-weigeraars-vragen-heropening-strafzaak a 3364018/ (accessed 26-o5-2020); 'Slachtoffer stelt Staat aansprakelijk voor marteling', de Volkskrant, 22-12-2014. http://www.volkskrant.nl/binnenland/slachtoffer-stelt-staat-aans prakelijk-voor-marteling a3816240/ (accessed 26-05-2020); Sterre van der Hee, 'Nederlandse Staat aansprakelijk gesteld voor verkrachting Indië', NRC Handelsblad, 27-1-2016. https://www.nrc.nl/nieuws/2016/o1/27/nederlandse-staat-aansprakelijk-gesteld-voor-ver krachting-indie-a1409810 (accessed 26-05-2020); Meindert van der Kaaij, 'Het komt er eindelijk: Een breed onderzoek naar geweld tijdens de dekolonisatie', Trouw, 2-12-2016. http://www.trouw.nl/tr/nl/4324/Nieuws/article/detail/4426748/2016/12/o2/Het-komt-ereindelijk-een-breed-onderzoek-naar-geweld-tijdens-de-dekolonisatie.dhtml (accessed 26-05-2020). 
pages reveal an entirely typical incongruity: the disrupted 'narration' of personal albums, especially in the absence of captions. Beneath the photographs of the execution in Jacobus R's album unspools a stream of unremarkable images of soldiers eating together and posing for group portraits. Based on my own recent research in three photographic war-time archives, ${ }^{28}$ as well as my work on amateur photography in the Netherlands East Indies (Protschky 2012, 2014, 2019), soldiers' albums frequently conform to the peacetime 'family album' genre, which favours scenes from everyday life and themes that emphasize social connections and domestic harmony (Hirsch 1981:12-3, 32, 111; Hirsch 1999:xi-xxv; Rose 2010).

With few dates or names, as is common in private albums, it is difficult to 'read' clear chronologies in most soldiers' photographs from the war, to discern a 'plot', and to make sense of interruptions to the monotony that are sporadic and often decontextualized-much like the photographs of executions that appear suddenly and without explanation among scenes of camaraderie in the Jacobus $\mathrm{R}$ albums. How should we interpret photographs of violence that disrupt what, to all intents and purposes, otherwise appears as a strange 'family' album (albeit one where the family is oddly homogeneous - an enclave of men, all around the same age)?

Far from advancing Noordzij's claim that, by and large, there is nothing further for us to see in Dutch soldiers' albums from the war, I argue that it is precisely in the photographic, post/colonial archive that soldiers made for themselves, each other, and their families, that we can extend historical examinations of how extreme violence was constituted, supported, and justified by Dutch combatants, during as well as after the war. The photographic archives I refer to from here onwards are by no means exhaustive, but they do encompass thousands of amateur Dutch soldiers' photographs across more than 140 individual collections ${ }^{29}$ and therefore constitute a significant sample upon which I base, if not a definitive conclusion, then some considered historical and theoretical arguments about the uses of this colonial archive in the postcolonial present. Many of the photographs are accompanied by surviving letters, diaries,

28 The entire collection of soldiers' photographs from the Dutch military operations in Indonesia (1945-1950) held at the Nederlands Instituut voor Oorlogs-, Holocaust- en Genocidestudies (NIOD, Institute for War, Holocaust and Genocide Studies), Amsterdam; a major part of the 'Sweep' Collection, 54: Egodocumenten Nederlands-Indië 1945-1950, at the Nederlands Instituut voor Militaire Historie ( $\mathrm{NIMH}$, Netherlands Institute for Military History), The Hague; and all the relevant holdings of the Special Collections of the Koninklijk Instituut voor Taal-, Land- en Volkenkunde (KITLV, Royal Netherlands Institute of Southeast Asian and Caribbean Studies), Leiden University Library. 
and other 'ego documents' (autobiographical sources) produced by the soldiers, their friends, and their families. Together, these textual sources provide crucial context for understanding the content, uses, and reception of the photographs.

Methodologically, I follow the 'social lives' of the photographic ego documents back to their points of origin, to their makers and initial audiences (Appadurai 1986; Edwards 2001:9, 13). I situate them within a visual economy where their functions-including their interaction with written and other sources-shape their meaning (Poole 1997). Reconstructing these functions enriches understandings of why photographs were made and for what purposes and audiences during the war, as well as the politics of memory surrounding their discussion in the postcolonial period. Theoretically, my analysis is shaped by scholarship that encourages us to use atrocity photographs not to pierce the fug of the present with the truths of the past, but to sharpen our understanding of how and why contests and obscurities form and persist around controversial histories - what photographic historian Jane Lydon (2016:66) calls 'blindspots'. As Lydon and Bijl, among others, have shown, photographs of atrocities may well circulate at the time of their making without shocking audiences, moving them to stop violence and oppression, or suddenly changing the discourses and practices that justify and enable brutality (Lydon 2012:52; Brown 2014:191; Bijl 2015a). The 'flash of recognition', to follow Lydon (2012), is often delayed well beyond the moment of a photograph's making and circulation and is partial rather than complete, following only from long periods of open debate and, often, activism by the people to whom violence has been done.

Apart from the cultural and historical specificities of context that shape the interpretation of photographs at and after their making, despite what the long record of horrors documented since the invention of photography in the mid nineteenth century suggests, atrocity is often only elusively captured on camera. Some acts are rarely photographed, notably sexual violence, and, as I have already shown, the details of cause, motive, and meaning are rarely selfevident. Given these ambiguities, Ariella Azoulay has taken the position that an 'atrocity photograph' is best understood as defined not by its content but by the context in which it is made. If it is born of disaster, then it is a photograph of atrocity (Azoulay 2012:251). Her definition may be construed as too general, perhaps, but searching in that direction-in and around the context of the atrocity and the 'everyday' situations that support and obscure it - is my point of departure in examining Dutch soldiers' amateur photograph collections. 
The circulation in the present day of Dutch soldiers' amateur photographs from the Dutch military actions in Indonesia has enabled a very public postcolonial afterlife for these object-images that is far removed from their point of origin. However, this is not to say that such photographs were formerly 'private', in the sense that we might expect of a personal diary, or that the deeds which they show have been 'hidden' up until now. On the contrary, soldiers' lives and the photographs that were made of them once circulated in what I call 'particular publics', within visual economies that can be reconstructed using a variety of techniques. These include attending to the annotations on or around them and, importantly, tracing their reproduction and exchange within social and military networks during and after the conflict. Reading the letters and diaries that soldiers produced often explains when and how photographs were taken, who they were shown to, and why. Archival provenance notes, where they include correspondence with donors who were relatives of soldiers, provide further insights into how the photographs were used 'at home', after the war, when soldiers returned from service. Together, these techniques reveal who saw soldiers' deeds and the amateur photographs that sometimes recorded them, both during the Dutch military actions in Indonesia and afterwards.

As the Jacobus R photographs demonstrate, Dutch soldiers' atrocities often had multiple bystanders and witnesses that were recorded in the frame of the photograph. The same is true of representations of 'conventional' killings in the war, such as the photograph of a Sumatran combatant felled in a street fight by Dutch forces in Palembang in January 1947 (Figure 1). This photograph is not uncommon in showing the Dutch soldiers who returned to the scene to inspect the deceased for identification. ${ }^{30}$

We cannot be sure that the photographer here was the A.J. Mickers whose collection it is from, not least because an exact copy of the same image also appears in two other soldiers' collections: G.M. Nafzger and C.A.H. Roksnoer. ${ }^{31}$ Although it is not certain how well they knew each other (if at all), the three men were definitely in the same infantry battalion together (3-RI) and served as storm troops. The archives provide multiple other examples of soldiers who seemed to share print copies of the same photograph, or else very similar pho-

30 See A.F. van den Burg A475o, Roksnoer A56o6, B. van Dijk BCo1o, G.M. Nafzger вC265 (folders A and B); all at Image Bank wwi , NIOD, Amsterdam.

31 Collections G.M. Nafgzer BC265 and Roksnoer A56o6, both at Image Bank wwII, NIOD, Amsterdam; see also Kok, Somers and Zweers 2015:155. 


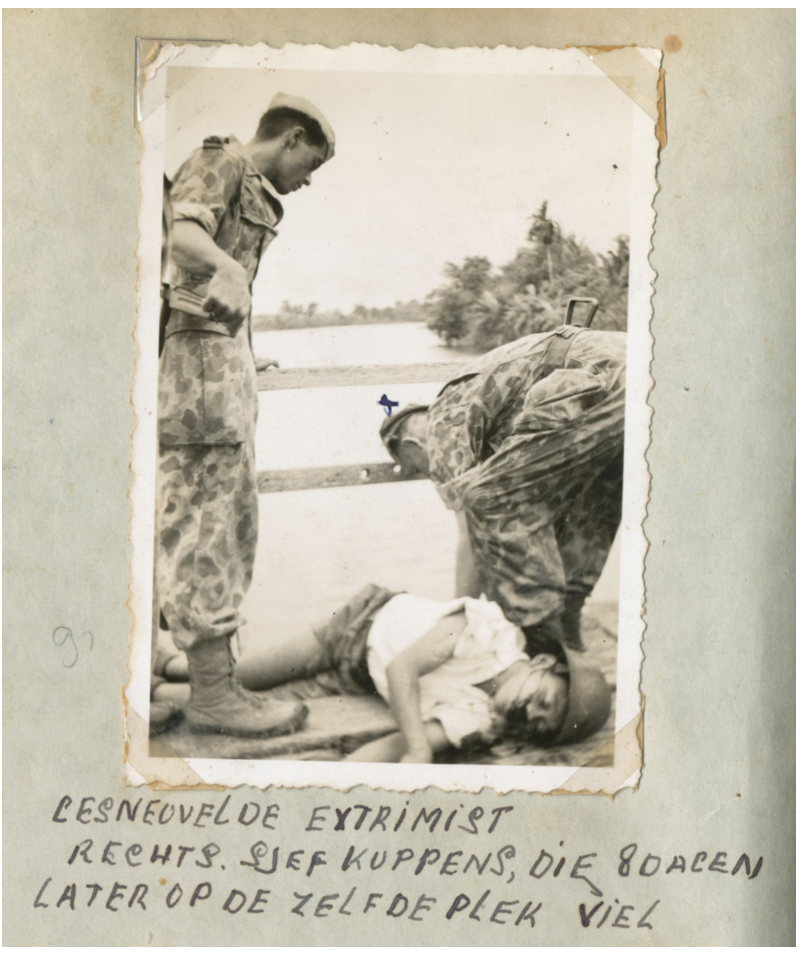

FIGURE 1

'Killed extremist [.]

Right [:] Sjef Kuppens, who fell on the same spot 8 days later'. From the album of A.J. Mickers IMAGE BANK WWII, NIOD, AMSTERDAM, BC508

tographs that were taken at the same scene. ${ }^{32}$ Soldiers' personal albums and collections of loose photographs were thus frequently constituted by multiple 'authors' and their overlapping social networks. Creation (taking the photograph) and curation ( selecting what to do with it) acts, performed by individuals, must therefore be recognized as distinct photographic practices among soldiers, with collective distribution frequently interjecting between these phases. Underpinning such sharing practices was a pooling of resources that were reasonably expensive for soldiers during the war (cameras and photo prints), as

32 Soldiers Roksnoer A56o6, Mickers BC508, and Nafzger BC265 all shared photo prints of a Chinese funeral, and Mickers and Nafzger had several other prints in common, besides the photograph of the killed Sumatran soldier. Soldiers Veeninga (no archive number) and Maaskant BC246 had similar photographs of Indonesians killed during an uprising in Bandung in 1950; Bob van Dijk, who was an embedded photographer, had in his collection several photographs of killed Dutch soldiers and Indonesians being taken prisoner that have been attributed to Hugo Wilmar, a Marinevoorlichtingsdienst (MARvo, Marine Information Service) photographer; see Kok, Somers and Zweers 2015:55, 63, 64. All collections cited here at Image Bank wwII, NIOD, Amsterdam. 
well as the social act of connecting through common experiences (the subjects that were represented in the photographs) that were meaningful to the soldiers.

At first glance, images like Figure 1 might be interpreted as 'trophy' photographs of enemies slain, and their taking and sharing as a celebratory pleasure taken in the violence of war (Roberts 2012). The caption to Mickers's copy, however, quickly dismissed the subject matter-an anonymous enemy, typecast as a 'killed extremist' - to remark on a death that was more important to him: that of his comrade, who 'fell on the same spot 8 days later'. The inked ' $x$ ' above the man on the right marks out 'Sjef' Kuppens, a Dutch soldier whose military funeral in Indonesia punctuated the rest of the album and clearly played on Mickers's conscience. By contrast, the caption to Roksnoer's copy seems to express regret at the Indonesian soldier's death ('he was too late'). ${ }^{33}$ Similarly, on the reverse side of G.M. Nafzger's copy of the same photograph, he had written the following thoughts:

Are these soldiers? Here, children! But they have a gun in their hands, so for our own safety we have to deal with them. ${ }^{34}$

All three captions reveal the early formation, perhaps during the war itself, of a narrative that regards the killing of young Indonesian men in various ways: one with indifference, the others with (some) regret. Neither caption explicitly describes what prompted the photographer (whoever that may have been) to take the picture in the first place. However, the sharing of photographs showing killed enemy combatants reveals that they had a contemporaneous photographic audience, from the moment that a camera was pulled out (the other Dutch soldiers in the picture) to a later time, when print copies were made and distributed to multiple soldiers. Photographic practices like copying and sharing were thus clearly important for constituting social relations and stories about what happened during the war among soldiers at the time of their service together.

I cannot reconstruct the audience for this particular photograph (Figure 1) any further, but from other examples it is clear that such objects circulated more widely, to friends and family on the 'home front', as demonstrated by notes addressed to recipients on the reverse side of prints. This is particularly true for men who were in the Koninklijke Landmacht, which consisted of

33 Roksnoer A56o6, Image Bank wwiI, NiOD, Amsterdam.

34 Collection G.M. Nafzger, BC265 (Folder B), Image Bank wwII, NIOD, Amsterdam. The youthfulness of Indonesian soldiers was also remarked upon in the soldiers' testimonies reproduced in Oostindie, Hoogenboom and Verwey 2015:99. 
volunteers and conscripts from the Netherlands. (Dutch men also served in, but made up only a minority of, the Koninklijk Nederlands Indisch Leger, or KNIL, which mainly recruited indigenous and Indo-European soldiers within Indonesia.) Letters that Dutch soldiers sent to friends and family in the Netherlands often discuss photographs, which can be identified from their collections, that must have been attached to their correspondence. ${ }^{35}$ Since archives often divide photographs from other sources, like letters and diaries, the paths that individual photographs travelled before they left private collections require reconstruction. Tracing these trajectories can involve reconstituting collections that soldiers had originally dispersed among different audiences, and were reunited with only once they had returned home themselves, when photographs were bundled together in the envelopes, tin boxes, or albums that archives later received them in.

Photographs that showed extreme or explicit violence were routinely withheld from correspondence that went to loved ones on the home front. The collection of Piet Kossen is a case in point. Kossen (1926-2014) was conscripted to the 'Tiger Brigade' of the Fifth Infantry Regiment (5-5R.I.), and stationed on Java from 1947 until 1949. His albums showed his involvement in patrols, 'cleansing actions' (zuiveringsacties), the taking of enemy prisoners, and the funerals of fellow soldiers. ${ }^{36}$ By contrast, Kossen's letters to his fiancée were almost entirely devoid of information on what his life at war entailed. Instead, they were repetitions on a theme of mutual affection, pining due to separation, and descriptions of Dutch social rituals that the two could celebrate at distance, such as birthdays and the annual celebration of Sinterklaas. ${ }^{37}$ That soldiers compartmentalized their wartime experience while still on active service, keeping silent on what they did in correspondence with family and friends, is well established in studies using letters and oral history (Oostindie, Hoogenboom and Verwey 2015:40-1; Wietsma and Scagliola 2013:114, 116, 184). But that patterned cultures of silence and (in)visibility pertaining to some people (those on the home front) and not others (soldiers) commenced during the war, through social practices that involved photographs, demands clearer recognition. More specifically, photographic practices were capable of opening up a

35 See, for example, G.M. Nafzger, A247, inv. no. 243, letter dated 29-11-1945, p. 2; inv. no. 244, letter dated 7-12-1947, and 15-4-1946; C.H. Vink, A247, inv. no. 584, letters dated 9-6-1946, p. 2, 8-8-1946, p. 2, and 19-9-1946, pp. 1-2; diary of J. Stegeman, A401, inv. no. 539, entries on 16-1-1946, 19-1-1946, 19-12-1946; P. Kossen, A5683, letter dated 2-7-1948; all at NIOD, Amsterdam.

36 Photograph albums, Kossen Collection, Image Bank wwiI, NIOD, Amsterdam, A5683.

37 Letters, Box 1 of 3, Kossen Collection, NIOD, Amsterdam, A5683. 


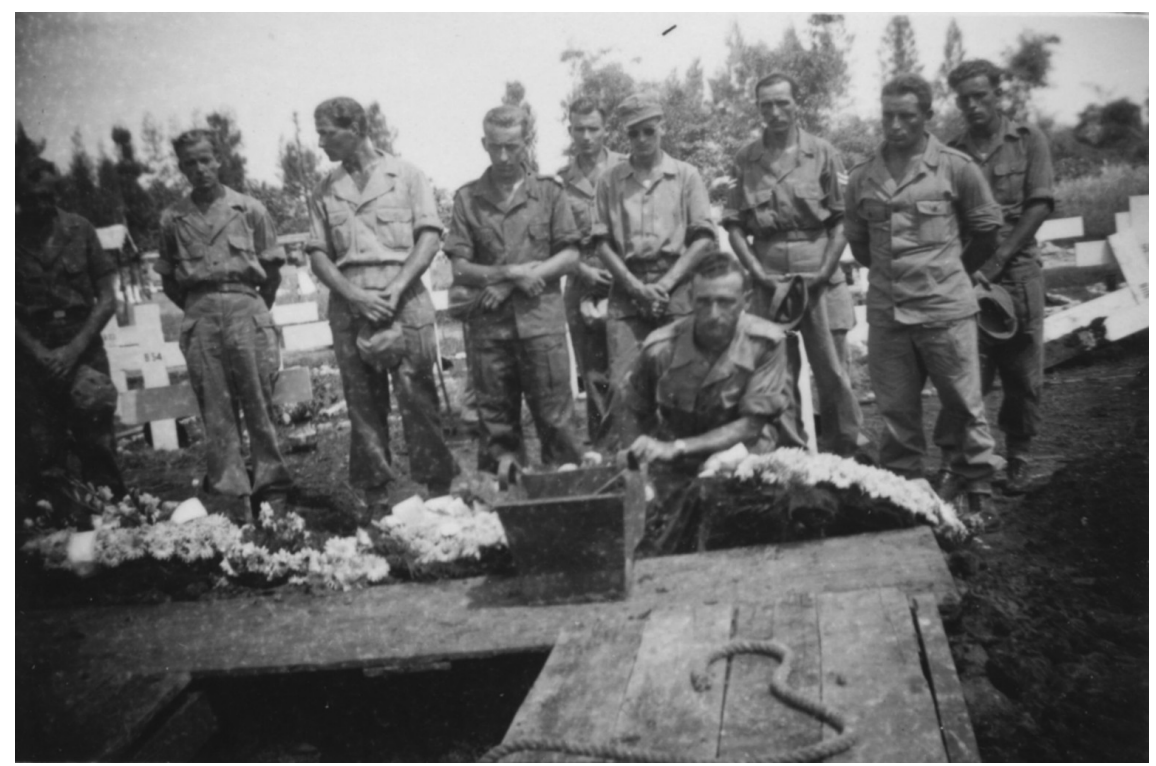

FIGURE 2 From the album of C.H. Vink

IMAGE BANK WWII, NIOD, AMSTERDAM, BC460

dialogue on violence among soldiers while disabling discussion with people 'back home'. Blind spots in the history of violence in the Indonesian War of Independence were therefore formed while Dutch soldiers were still on the job. They did so in part by selecting the audiences among whom some photographs of violence, but not others, could be seen.

The home front was not shielded from all images of violence. While there was effective censorship during the war of images of Dutch (and Indonesian) casualties (Zweers 2014), soldiers extensively photographed and sent home pictures of the funerals of comrades killed in action (Kok, Somers and Zweers 2015:145). In many cases, it is clear from collections of amateur soldiers' photographs that these images were taken as memento mori for the dead soldiers' families. In the album kept by the younger brother of C.H. (Kees) Vink (19241948), who was killed in action shortly before he was due to be repatriated, the album ends with photographs of his funeral, in which one of the soldiers in attendance looks pointedly into the camera, as though addressing the family he knows will be receiving the image (Figure 2 ). In contravention to media censorship practices, such photographs were directed to an audience- the dead soldier's family and friends - and emphasized the personal connections and funeral rites that were disrupted by the distance between the home and war fronts. 
The strategies that soldiers adopted for compartmentalizing their lives while on active duty, aided by photographic practices, can in some instances be tracked into the decades after the war, when soldiers were demobilized and repatriated. Provenance files relating to the transfer of soldiers' collections to archives often contain statements and correspondence from donors. The story of such divestments - of the process by which private collections are given over to the public sphere of the custodial institution, where anyone (in principle) can view them-is fundamental to the formation of the postcolonial archive. These are the moments when ostensibly intimate, 'family' photographs leave the home and reach new audiences, none of whom the original makers and owners of the photographs were addressing. It is a tenuous moment in the social biography of any archival object, because the actors in divestment are rarely seen by archives as part of the story, which is instead assumed to inhere in the collection that is passed on. It is also this process, and all the patterns of visibility and invisibility that I have traced to this point, which stories of the miraculous recovery of 'forgotten' or 'abandoned' atrocity photographs elide, and which a juridical motive - 'these photographs have not been in the public domain because they are incriminating'-inaccurately homogenizes. There are many more archival collections of photographs of atrocity than there have been media stories about their existence, and for every such photograph, there are networks of soldiers, family, and friends who had once seen it.

Provenance records can provide an insight into soldiers' longer-term reflections on their wartime experience, including what they had to say about their photographs after the conflict and when once again among the civilian population of the Netherlands. In the Institute for War, Holocaust and Genocide Studies (NIOD) collections, provenance records are reasonably detailed. Some donors attest to having spoken at length with the veteran in question about his wartime photographs, to the extent that they knew precisely which of them he personally had taken. ${ }^{38}$ Others reveal that veterans had been reluctant to talk about the war. ${ }^{39}$ One woman wrote of her father-in-law's items: 'The photos tell us nothing. Earlier they were not spoken about, nor can we ask family members about them as they have all passed away. ${ }^{\prime 0}$ Most of the Dutchmen who fought

38 See the provenance notes for the collections F.R. van Mourik BC470/A4386, A.F. van den Burg A475o, and K. Bron BC457; all at NIOD, Amsterdam. Soldiers' published memoirs were often the logical conclusion of soldiers telling their families of their experiences in the first instance; see Oostindie, Hoogenboom and Verwey 2015:43.

39 See the provenance note for Collection P. Kossen, NIOD, Amsterdam, A5683.

40 Letter from G. Benink to NIOD, 18-12-2008, BC531; see also Oostindie, Hoogenboom and Verwey 2015:47. 
in Indonesia were in their early twenties, with spouses yet to meet and children still to conceive. The confinement of their wartime service to their youths, before the onset of familial responsibilities, is addressed by the widow of a former soldier, who wrote of his '[p] hotos from the time before I knew him. [...] I don't know the details. ${ }^{41} \mathrm{~A}$ son who could not identify his father in a collection said: 'My mother has always looked after these, but she has had dementia for several years and there is no reason for me to keep them any longer. My father himself is (voluntarily) not in a single photo. I presume that he took most of them himself.'42 The photograph album, despite its bookish appearance, rarely tells a coherent story and struggles to narrate itself once there is no voice living or willing to recount the events and social relations connecting the people in photographs to a narrator who knows them. These records confirm Martha Langford's work on the 'oral-photographic framework' that personal photographs rely on for their coherence and goes some way towards explaining how their meaning can, in some circumstances, quickly fade into obscurity (Langford 2001, 2006).

Among military veterans' organizations we have a broader public, larger than the personal networks that soldiers maintained within and beyond Indonesia during the conflict but confined to a particular community, with its own organs, agenda, and subculture. It would take sociological or anthropological research, or perhaps oral history, to shed light on how soldiers used their amateur photographs at veterans' meetings or in veterans' homes ${ }^{43}$ which is beyond my scope here. What is clear, however, is that soldiers' amateur photographs entered military publications during the war and veterans' commemorative books afterwards. As scholars have noted, Dutch military organizations actively encouraged soldiers to be amateur photographers during their service in Indonesia. Blank albums were issued to soldiers by the Dienst Welzijnsverzorging (Welfare Service) to encourage correspondence with a Dutch home front still reeling from the Second World War and faced, from 1946, with conscription (Kok, Somers and Zweers 2015:144). ${ }^{44}$ NIOD has several examples of such albums, whose implicit aim to reassure family and friends in the Netherlands is promoted by cover titles like 'Memories of my service period overseas / in the tropics', which evoke a pleasant journey rather than a tour of duty. ${ }^{45}$

\footnotetext{
41 Printed email from H. Cordang-Lievegoed, 2-11-2012, NIOD, Amsterdam, BC543.

42 Letter from J. Huijerman, 22-11-2012, NIOD, Amsterdam, BC546.

43 There are oral-history collections, such as at https:/www.veteraneninstituut.nl/diensten/ interviewcollectie/; see also Scagliola 2002; Limpach 2016.

44 Conscripts ultimately comprised 100,000 of the 150,000 soldiers who were sent from the Netherlands (Oostindie, Hoogenboom and Verwey 2015:19).

See albums in collections C.H. van Leeuwen вС247, Cordang вС543, J. Boon вС446, C.J. van
} 
Newsletters produced by Dutch forces in Indonesia during the war encouraged soldiers to share their photographs for publication. The bulletin De Mortier van 5 , for instance, which was published between 1946 and 1950 for the 'Tiger Brigade' in which Piet Kossen served, claimed to be 'the voice of the young men of 5-5-RI', and published advertisements for soldier's photographs:

Apart from your friends and girlfriends, there are actually more people who are interested in your photographs. Send the negatives or your photographs of events in the battalion immediately to the editors. ${ }^{46}$

The official publications produced for military divisions, which described and commemorated campaigns, acknowledged the use of photographs that were made by soldiers in the field (see for example Blom 1950:70). These venues enabled soldiers' amateur photographs to circulate in a circumscribed yet substantial public sphere, for an audience of other soldiers across all ranks, including among military authorities. Their photographic content is often remarkably similar to the photographs in soldiers' private collections, traversing almost every theme except for explicit cases of extreme violence. The same is true of illustrated publications produced by veterans' organizations after the war (for example, Behrends 1993; Van Dreumel 2008). One of Piet Kossen's photographs of prisoners taken during a 'cleansing action' in April 1949 (Figure 3) was reproduced in the fiftieth-anniversary commemorative book for veterans of his battalion (Schouten, Venneboer and Bijker 1997). Together, contemporary and post-war military publications broaden the audience, in size and across time, for the kinds of photographs that Dutch soldiers serving in Indonesia were already sharing among themselves and with their friends and family through correspondence.

Contrary to the present discourse surrounding the recent publication of a small number of execution photographs from the war, then, the audience for soldier's amateur photographs was never closed, like the pages of a diary, even for some categories of photographs that were withheld from the press during the war. Dutch soldiers' photographs had contemporary audiences, particular publics whom soldiers selectively addressed throughout their lifetimes. These publics included their peers on the front, their social networks in the Netherlands, and the military and veterans' organizations that employed and, later, represented them as (former) soldiers. Granted, this is not the broad, ideal

Drongelen вC458, C.H. Vink вC46o, F.R. van Mourik вC470, and K. van Wijk вC432; all at NIOD, Amsterdam. See also Kok, Somers and Zweers 2015:90-1, 103.

46 De Mortiervan 5, 9-10-1948, p. 2: Kossen Collection, Box 2 of 3, NIOD, Amsterdam, A568. 


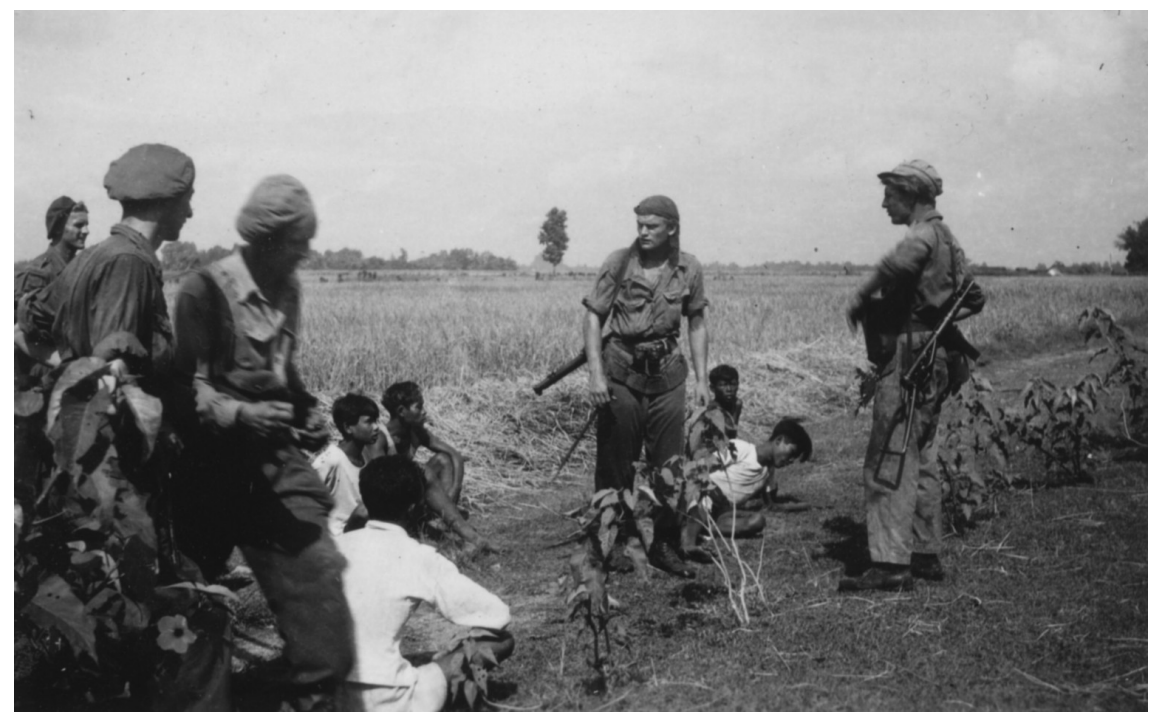

Figure 3 Personal album of Piet Kossen, from a section titled 'Cleansing action on the way to Pijoengan [Piyungan], 26 April 1949'

IMAGE BANK WWII, NIOD, AMSTERDAM, A5683

public sphere addressed by journalists and press photographers, but it is too large and significant a community to give continued credence to the notion of 'private' amateur soldiers' photographs and the historical oblivion that the recent execution images purportedly emerge from.

Having established that amateur Dutch soldiers' photographs from the Indonesian War of Independence circulated during and after the late 1940s within a visual economy comprising what we might call social and professional publics, it remains to examine what the content of such photographs can reveal of the nature and extent of extreme violence during the conflict. Doing so first requires recognition that looking through the camera lenses of Dutch soldiers provides only part of the picture: in this perspective, we miss the authorship of Indonesian combatants and civilians, who instead figure in this archive as subjects.

Compared to other topics in Dutch soldiers' amateur photographs, images of Indonesian combatants are in the minority. Perhaps the reason is selfexplanatory. If a soldier was engaged in fighting then he was unlikely at that moment to pull out a camera and take a picture of his enemy. The execution 
photographs discussed so far are indeed rare. Nonetheless, there are enough additional photographs in the archives to warrant further research into whether they were taken in 'conventional' circumstances or in conditions of extreme violence. Put differently, there exists a much larger archive of visual evidence for atrocities committed by Dutch soldiers than the small number recently circulating in the public sphere suggests. Where Indonesian combatants feature in soldiers' collections, they fall into one of two categories: as slain fighters or as live prisoners. Both show 'the enemy' as vanquished by Dutch soldiers. As we have seen, Dutch combatants did photograph and sometimes share prints of Indonesian soldiers killed in battle (Figure 1) ${ }^{47}$ They also regularly photographed Indonesians who had been taken captive (Figure 3) ${ }^{48}$ Limpach (2016) has demonstrated that the taking and interrogation of prisoners were situations where systematic violence occurred. It is these photographs, which figure so often in Dutch soldiers' collections, that perhaps need to be reconceived as 'trophy photographs' that fetishized violent contexts while eschewing violent content.

Following Azoulay's appeal to look for the contexts of atrocity in photographs, not just its grimmest expressions, there are more examples of photographs that are potential sites for further research into evidence of extreme violence. We know from recent historical works, for example, that routine operations such as patrols and cleansing missions were common contexts in which atrocity occurred (Kok, Somers and Zweers 2015:5; Limpach 2016). Dutch soldiers were far more likely to focus their lenses on each other rather than on enemy combatants. Their amateur collections frequently show comrades posed with weapons or military vehicles while on patrol or undertaking a cleansing action (zuiveringsactie), contexts that soldiers made explicit through captions in albums and notes on the reverse side of photographs. Such images, many of them involving a degree of staging, exposed the Dutch military's capa-

47 Across the following collections, I found a total of 25 photographs of Indonesian soldiers killed in battle: A.F. van den Burg A475o; Bob van Dijk BCo1o; G.M. Nafzger BC265 (Folder A), (Folder B); B. van Dijk BCo10; G.G. Oudt (no archive number); J. Maaskant BC246; A.J. Mickers вС508; Veeninga (no archive number); Malta вс367; all at Image Bank wwII, NIOD, Amsterdam.

48 Across the following collections, I found a total of 28 photographs in this category: A.F. van den Burg A475o; B. van Dijk BCo1o; Berends BC40o; D.J. van Hattum (no archive number); J.G. Vooges (no archive number); K. van Wijk вC432; P. Kossen A5685; unknown soldier BC537; Van Rooij вС434; Malta вС367; all at Image Bank wwII, NIOD, Amsterdam; and Collection Nieuwenhuyzen, Album 216, KITLV Special Collections, Leiden. Limpach (2016:439-59) reproduces more such photographs and interrogates the conditions under which prisoners were held and questioned. 
city for violence while rendering its victims invisible. They were regularly the material of military publications and contemporary press photographs, precisely because they pictured sanitized forms of action.

Given my contention that there is more to see on the nature and extent of violence during the war in Dutch soldiers' albums than a narrowly defined image of atrocity enacted, it is also necessary to examine the subjects that figure most frequently (apart from themselves) in Dutch soldiers' amateur images from the war: Indonesian civilians. Soldiers devoted an inordinate amount of space in their photographic collections to life in the billet or the barracks-a domestic sphere of sorts, albeit an overwhelmingly homosocial one, punctuated by the presence of a few young Indonesian women who provided housekeeping services. ${ }^{49}$ At first glance, these women represent a continuation of colonial-era household structures. Families of all classes and ethnic groups routinely employed local domestic servants in the late nineteenth and early twentieth centuries, and photographs featuring these workers are a strong feature of colonial family albums (Saptari 2011; Westerkamp 2012:112-5; Protschky 2012). As Annegriet Wietsma and Stef Scagliola (2013:8) have shown, during the war female Indonesian servants provided additional services to Dutch soldiers, including companionship and sex, which resulted in thousands of children who were abandoned when the soldiers returned to the Netherlands (see also Wietsma 2010). As I have argued elsewhere (Protschky 2020), the households that Indonesian women supported through their labours for Dutch soldiers, and that were openly and extensively alluded to in their amateur photographs (Figure 4), are in urgent need of re-examination as a 'package of services' provided under conditions of social and economic duress. After all, such labours - which materially and emotionally benefitted soldiers and reassured the home front with images of domestic order-were provided in a social field shaped by militarized violence and built on histories of colonial race relations. That photographs showing Indonesian women as domestics in soldiers' garrisons were widely placed in their personal albums speaks to the strategic significance of the war 'home' front (the one on Indonesian soil) for Dutch soldiers. ${ }^{50}$ Photographs showing the relationships of Dutch combatants with

49 Such photographs were also favoured by the Dutch news media at the time (Kok, Somers and Zweers 2015:67).

$5^{\circ}$ See 31 examples across the following collections: J. de Raad вС236; C.H. van Leeuwen вС247; F.R. van Mourik вC470/A4386; I. Janssen вC526; Cordang вC543; D.J. van Hattum (no archive number); G.G. Oudt (no archive number);J.C. Hunselar BC465; J.G. Vooges (no archive number); K. van Wijk BC432; K. Bron BC457; P. Kossen A5683; unknown soldier BC456; Ph. van Veen BC519; W.B. Pitts A5665; all at Image Bank wWII, NIOD, Amsterdam. 


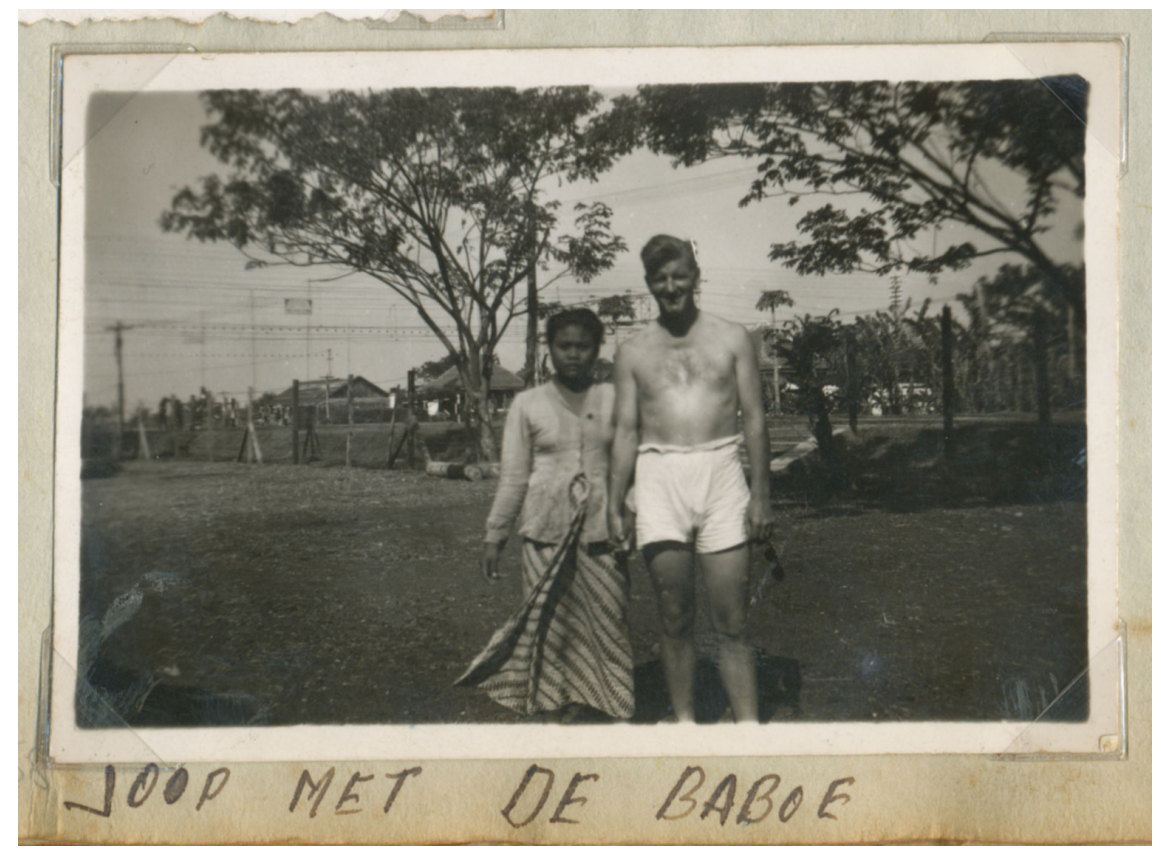

FIGURE 4 'Joop with the baboe'. Collection A.J. Mickers

IMAGE BANK WWII, NIOD, AMSTERDAM, BC508

Indonesian women thus constitute a significant but overlooked archive, which addresses how gendered and racialized structures of violence with a long history in Indonesia played out in the late 1940s.

The picturing of Indonesian civilians in Dutch soldiers' amateur photographs is as crucial to understanding the nature of violence in the war as is the representation of combatants. By far the most pervasive images of explicit violence in Dutch soldiers' photographs are of civilian lives disrupted: of towns and villages that have been razed, and of local people who have been killed, including instances where atrocities were almost certainly committed against them by other Indonesians. In this regard, Dutch soldiers captured the elements of a civil war that was unfolding between Indonesian militias and political factions who were fighting on (at least) two fronts: against each other and against a colonial counter-insurgency (Poeze 2014). As Dutch soldiers participated in actions that involved the reconquest of territory from Indonesian forces, they diligently documented the massacre of Chinese Indonesians, who

See also Collection A.H.O. Bos, albums 1177, 1178, 1179, at Special Collections, Leiden University Library. Further examples are reproduced throughout Wietsma and Scagliola 2013. 
were the subject of reprisals and pogroms during the conflict. ${ }^{51}$ Contrary to recent claims that amateur soldier photographers 'self-censored' when it came to capturing images of extreme violence (Kok, Somers and Zweers 2014), ${ }^{52}$ the archives show they also photographed the massacre of women and children in villages, ${ }^{53}$ a topic I shall return to in the final section.

Beyond the violence inflicted upon them, the severely straitened circumstances of Indonesian civilian populations was a subject widely recorded in amateur soldiers' photographs. Almost every collection contains images of women and children affected by disease and malnutrition. Many soldiers made a study of suffering bodies wasted by hunger or ravaged by illnesses visible to the naked eye. Cases of yaws, commonly known in the 1920s and 193os as (tropical) framboesia, a bacterial infection that causes spreading lesions on the skin and flesh, particularly seemed to fascinate and appal soldiers. ${ }^{54}$ The photographs of Albert Bos (1906-1996), 55 a lieutenant in the KNIL, are exemplary in this regard. Bos's caption to a series of photographs of emaciated yaws sufferers in his album, which repeats caustically over six consecutive pages-'This is the population under the Republic' - lays the blame for the suffering of civilians squarely with Indonesian Republican forces. The album's photographic narrative makes invisible the part that Dutch soldiers played in the conflict and their effects on civilians, ${ }^{56}$ while the text foregrounds the visibility of what might be termed the enemy's 'atrocities of neglect' (Protschky 2018).

Bos's combination of image and text is perhaps the most eloquent example, but it is a sleight of hand, and of the lens, that recurs in other amateur soldiers' photograph collections. ${ }^{57}$ The image of Indonesian civilians suffering also fea-

$5^{1}$ See, for example, the collection of G.G. Oudt (no archive number), Image Bank wwiI, NIOD, Amsterdam. See also Somers Heidhues 2014:155-75; Kok, Somers and Zweers 2015: 34 .

$5^{2}$ The authors quote from soldiers who wrote that they had witnessed such atrocities (p. 103) but claimed that they demurred from photographing them (p. 145).

53 See A.F. van den Burg A475o; K. van Wijk BC432; Roksnoer A56o6; all at Image Bank wWII, NIOD, Amsterdam; and Collection Nieuwenhuyzen, Album 216, Special Collections, Leiden University Library.

54 See collections of J. de Raad вс236; B. van Dijk вCо1о; D.J. van Hattum (no archive number); all at Image Bank wwII, NIOD, Amsterdam; and A.H.O. Bos, Album 1177, Special Collections, Leiden University Library.

55 Albums 1175-1180 and Archive H179o, Collection Albert Henry Oswald Bos in Indisch Wetenschappelijk Instituut (IWI) Collection, Special Collections, Leiden University Library.

$5^{6}$ Dutch forces blockaded Republican-held areas, for example, and therefore contributed to supply shortages (Kok, Somers and Zweers 2015:128).

57 On the reverse of a photograph in the collection of A.F. van den Burg (A475o), which 
tured strongly in the Dutch media at the time (Zweers 2014:76, 95) and in official and unofficial military and veterans' publications both during and after the war, $^{58}$ often with evidence of their miseries being ameliorated by Dutch soldiers in the frame. In soldiers' collections, photographs abound of spontaneous acts of giving their own rations to dishevelled or naked children and of more organized programmes where food was systematically distributed to lines of women and their families at Red Cross or even military depots. ${ }^{59}$ Soldiers also routinely photographed clinics staffed by Dutch military doctors treating civilians for sickness as well as injuries. ${ }^{60}$

Photographs that position Dutch soldiers as humanitarians, rather than as counter-insurgents and re-colonizers, visually express the official framing of Dutch military actions as restorations of peace and order. This narrative was encouraged by the Dutch press and the military high command, and amateur photographs provide the clearest demonstration of the extent to which ordinary soldiers internalized this message-perhaps particularly those in the Koninklijke Landmacht, which comprised of conscripts and volunteers from the Netherlands. These photographs, which ostensibly place the suffering of

shows an emaciated woman and child, is written 'During TRI rule'. In the Berends collection (BC40о), on the reverse of one photograph showing Dutch soldiers distributing food to civilians is written 'The Republic is hungry', and on another showing a kampung burning, 'Bringers of security and justice?'. D.J. van Hattum (no archive number) had a photo of two starving children with the caption 'An image of the welfare left behind by the TRI in Masing'; all at Image Bank wwII, NIOD, Amsterdam. See also similar sentiments in soldiers' published memoirs and diaries (Oostindie, Hoogenboom and Verwey 2015:9, 27, 49, $55,78-9$ ).

58 See, for example, commemorative books published during and shortly after the war in the ego document collections at NIOD, Amsterdam: in R. Veeninga (no archive number), Portielje 1949:17, 19; in P. Kossen (A5683), Brouwer 1948 and Blom 195o:6o; in J. Huijerman (вC546), Van der Meulen 1947.

59 Photographs of soldiers giving their own rations to civilians are found in the following collections: A.F. van den Burg A475o; Roksnoer A56o6; D. van der Vlist BC539; B. van Dijk вСо1о; Berends вС4оо; J. Huijerman вС546; K. Bron вC457; P. Kossen A5683; Van Rooij BC434; all at Image Bank wWII, NIOD, Amsterdam; and Collection A.H.O. Bos, Album 1180, Special Collections, Leiden University Library. Photographs of organized Red Cross or military distribution of food to civilians are in the following collections: unknown soldier вС53о; J.J. Abbo вС5О7; K. van Wijk вС432; Van Broeckhuijsen вС433; all at Image Bank WWII, NIOD, Amsterdam; and Collection Nieuwenhuyzen, Album 216, Special Collections, Leiden University Library. See also examples in Kok, Somers and Zweers 2015:134-7.

6o See photographs in the collections of A.F. van den Burg A475o; Roksnoer A56o6; J. de Raad вC236; Goemaat BC435; D.J. van Hattum (no archive number); J.C. Hunselar BC465; J.J. Abbo вС507; G.M. Nafzger вС265; A.J. Mickers вС508; Van Broeckhuijsen вC433; W.B. Pitts A5665; all at Image Bank wwII, NIOD, Amsterdam; and Collection Nieuwenhuyzen, Album 216, Special Collections, Leiden University Library. 
local innocents at the centre of the picture, also implicitly feature the suffering of Dutch soldiers behind the lens: as witnesses of atrocities of neglect perpetrated by someone else. Suffering through the eyes of Dutch soldiers thus most often looks like something in which they played no part, except as empathetic spectators or humanitarian actors (Protschky 2018). Further, soldiers' views of themselves as humanitarians appear more consistently expressed in amateur photographs than in written autobiographical sources, such as published memoirs and diaries (Oostindie, Hoogenboom and Verwey 2015:9), reflecting perhaps the darkening of veterans' assessments of their part in the war as time passed.

Such perspectives are magnified by the numerous photographs in amateur collections that show good relations between Dutch soldiers and Indonesian civilians. ${ }^{61}$ Dutch soldiers seemed at pains to photograph themselves together with local children (Figure 5). The extent to which such images signal the emergence of a new genre in the photography of colonial humanitarianism, as recent scholarship suggests (Suski 2009; Bijl 2015a; Fehrenbach 2016), remains to be traced for studies of Indonesia. It could also be argued that contact with children, much like the company of women, provided a semblance of normality for soldiers, who lived mostly among men of their own age, many of whom were separated for long periods (up to three years) from family and friends. Like Indonesian women, children were similarly recruited to provide the comforts of 'home' to men at war, and their inclusion in soldiers' personal photographs is entirely in keeping with the domestic spaces that are evoked in 'family' albums. For engaged men like Kossen, a cuddle with two children (Figure 5) may well have been a preferable image to send back to his fiancée than one of him in an intimate setting with a young Indonesian housekeeper (as in Bos, described above).

Some of these photographs appear the outcomes of encounters with anonymous children. The captions to others suggest that the children were known to Dutch soldiers (sometimes by name), ${ }^{62}$ and were in fact working for them,

61 See examples in the following collections: Roksnoer A56o6, one of which has the caption 'friendship with the population'; De Jong вC244; D. van der Vlist BC539; B. van Dijk вCO1O; Berends BC40о; Goemaat BC435; Cordang вC543; D.J. van Hattum (no archive number); J.G. Vooges (no archive number); J.J. Abbo вС507; D. Elijzen вC432; K. Bron вC457; G.M. Nafzger BC265 (Folder A); P. Kossen A5683; A.J. Mickers BC508; Van Rooij BC434; R. Veeninga (no archive number); W.B. Pitts A5665; all at Image Bank wwII, NIOD, Amsterdam. Intelligence agencies, by contrast, often held photographs (which were never published) that showed a silent, reticent reception from local populations when Dutch troops rolled into a town (Zweers 2014:68-9).

62 See D.J. van Hattum (no archive number), who mentions a toddler named 'Henkie' and 


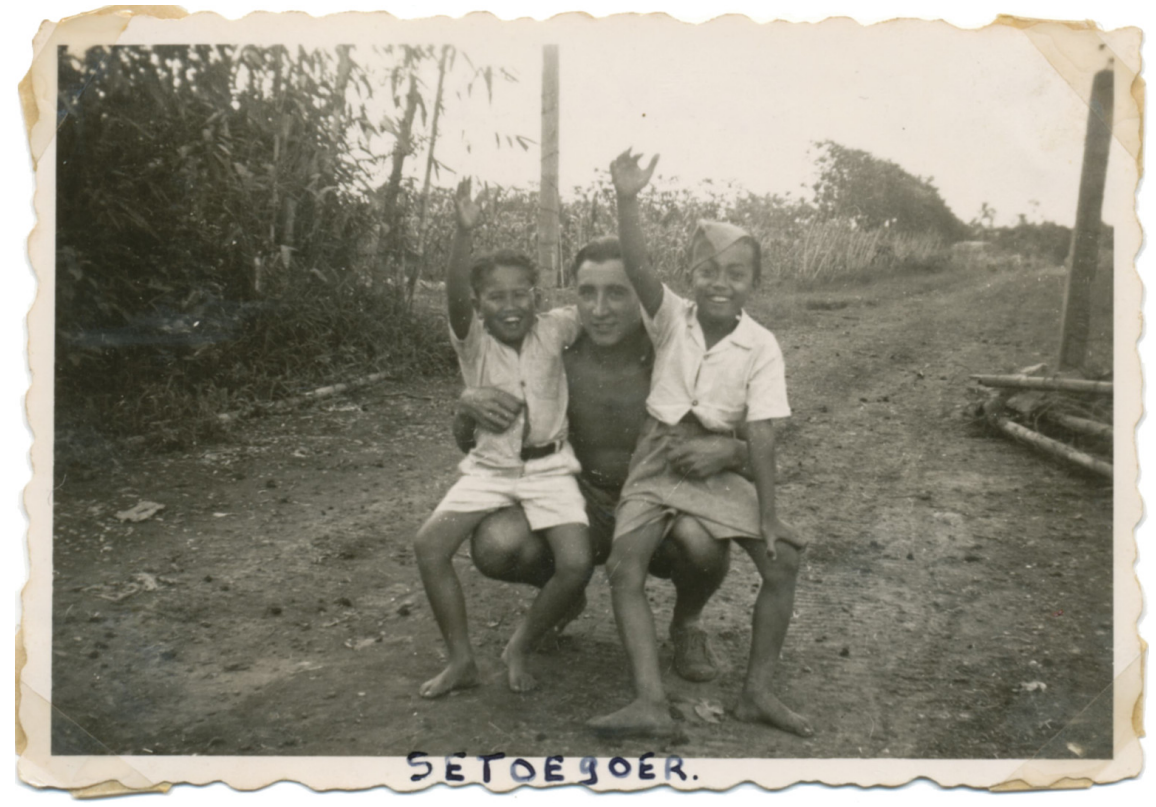

FIGURE 5 Collection of P. Kossen

IMAGE BANK WWII, NIOD, AMSTERDAM, A5683

as 'houseboys' or errand-runners. ${ }^{63}$ Soldiers' photographs of cheerful or charitable encounters thus elide the fuller story: the realities of a wartime economy, following hard on the heels of the deprivations many Indonesians experienced

refers to the Dutch soldier with him as his 'adopted father' (met $z$ 'n pleegvader); and $\mathrm{Ph}$. van Veen BC519, who mentions 'our houseboys (djongos-djongos) Carlos en Justinus'; and A.J. Mickers BC508, who similarly names his houseboy, 'Hasan'; all at Image Bank WWII, NIOD, Amsterdam. See collection of Lieutenant-Colonel J.A.C.H. van Welzenes and the children named 'Keesje' and 'Mipi' in his album, Folder 253, Album IV, NIMH, The Hague.

63 See examples in Roksnoer A56o6, in which a caption for a photograph taken during an inspection by General Spoor, showing two children in uniform, says 'Our little children are also present' (Onze peti (sic) kinderen zijn ook aanwezig). Limpach (2016: plate 6o) suggests that Indonesian children orphaned by the conflict were sometimes 'adopted' into Dutch platoons. D. van der Vlist BC539 mentions 'our boys' in a photograph of young boys taken in a courtyard where clothes and sheets are drying; Berends BC40o shows the children of domestic staff as part of the personnel; I. Janssen $\mathrm{BC}_{52} 6$ refers to five youths as 'the workboys (werkjongens)', and to boy servants as 'our houseboys'; Van Broeckhuijsen BC433 refers to some children as 'our coolies'; photographs of children working for soldiers are also in K. van Wijk BC432 (1); Ph. van Veen вC519 (1); A.J. Mickers BC5о8 (1); all at Image Bank WWII, NIOD, Amsterdam. 
under the Japanese occupation (1942-1945). ${ }^{64}$ They also sanitize the longer history of child labour that existed in Indonesia, particularly in rural economies, and that was formally incorporated in the Dutch colonial economy, on plantations, and in domestic service (White 2004), of which these transactions were clearly a continuation.

Together, these amateur photographs of suffering civilians, and of 'good' soldiers on friendly terms with villagers, extend the home front that supported the living of Dutch combatants, materially and emotionally. They also visually justified the Dutch war effort as a humanitarian action, a logic that other sources suggest became increasingly necessary for many soldiers as the war dragged on and the original grounds of their deployment lost its relevance (Oostindie, Hoogenboom and Verwey 2015:9). These photographs literally illustrate how, in many ways, the war was about civilians - about which government (a Dutch colonial authority or an Indonesian one) claimed sovereignty over the Indonesian subjects - and fought with images of civilians. The Dutch myth of the 'police action', in the absence of a formal declaration of war, was sustained by photographs of the rescue of 'innocent' civilians by European protectors from the grip of local 'terrorists' and 'extremists'. As Azoulay has eloquently proposed in another context, colonized people depicted as vulnerable to disaster are routinely implicated, in the occupier's photographs, as one of the disaster's causes rather than its effects (Azoulay 2011:36; see also Brown 2014:187-8).

Further, in positioning Dutch soldiers not as partners in and perpetrators of violence, but as witnesses to it, their own photographs imbricate them in a discourse of suffering, as veterans traumatized by what they have seen, and therefore deserving of special status and services upon their return to civilian life (Oostindie, Hoogenboom and Verwey 2015:276, 292-300). These are perspectives that bear directly on the postcolonial interpretation of the war, and the history of veterans in gaining welfare and political rights in its aftermath. That the pain of Dutch soldiers can be at the forefront of photographs showing suffering Indonesians has already been confirmed: the press release of the execution photographs from the Jacobus $\mathrm{R}$ album was followed by attempts by two veterans to obtain a formal pardon for jail sentences they were given for conscientiously objecting to conscription, which they claimed had been based on not wanting to participate in extreme violence. ${ }^{65}$

64 Oostindie, Hoogenboom and Verwey (2015:84) also mention the uses of the local population by soldiers. Zweers recounts the ambiguous reception of a photograph published in the Dutch media at the time that showed Indonesian children repairing a damaged road, with opinions divided over whether the labour was voluntary or coerced (Zweers 2014:55).

65 'Indië-weigeraars vragen heropening strafzaak', Algemeen Dagblad, 15-12-2012. http://www 
Looking at atrocity through the eyes, and photographs, of Dutch soldiers thus raises questions of ' $[\mathrm{w}]$ ho benefits from the production of empathy and in what circumstances?' (following Lydon 2016:xiv). If the overwhelming record of soldiers' amateur photographs reconfigures their presence in Indonesia as humanitarian rather than counter-insurgent, and as witnesses rather than perpetrators of suffering, does the visibility of this narrative not go further to account for black spots in the politics of memory around the war than the invisibility, or rarity, of evidence to the contrary?

As I have shown, when the Jacobus R photographs were published in the Dutch media, responses in the public sphere were dominated by Dutch veterans of the conflict, the men behind the camera lenses. Some reacted defensively, seeking to throw doubt on the veracity of the atrocity claims; some corroborated the claims by identifying themselves in the photographs (or in similar photographs); others sought to position themselves as victims of the conflict who had never wanted to participate in extreme violence. Most of the scholarship on this war is still in Dutch, with only one recent study being translated into Indonesian (Oostindie 2016), but as it internationalizes, the countless Indonesians who were photographed by Dutch soldiers will be brought more sharply into the picture. Initial reactions in Indonesia to the Jacobus R execution photographs concentrated on the evidence they furnish of the Netherlands' poor historical record of upholding human rights. In the Netherlands, this was interpreted as a reprisal for recent Dutch criticism of contemporary Indonesian human rights abuses. ${ }^{66}$ Beyond the implications for formal relations between the two countries, however, what will it mean for Indonesians to look not just at atrocity photographs, but more broadly, as I have tried to encourage with the examples I chose to reproduce, at photographs of 'everyday soldier-

.ad.nl/buitenland/indie-weigeraars-vragen-heropening-strafzaak $\sim$ aarb98c6 / (accessed 26 -o5-2020); 'Indië-weigeraars vragen heropening strafzaak', Trouw, 15-12-2012. http://www .trouw.nl/tr/nl/4324/Nieuws/article/detail/3364018/2012/12/15/Indie-weigeraars-vragenheropening-strafzaak.dhtml (accessed 26-05-2020); 'Indië-weigeraars vragen heropening strafzaak', de Volkskrant, 25-12-2012. http://www.volkskrant.nl/politiek/indie-weigeraars -vragen-heropening-strafzaak a3364018/ (accessed 26-o5-2020).

66 Laura de Jong, 'Dat Nederlanders als beesten tekeer zijn gegaan, wordt er hier met de paplepel ingegoten', de Volkskrant, 11-7-2012. http://www.volkskrant.nl/magazine/-dat -nederlanders-als-beesten-tekeer-zijn-gegaan-wordt-er-hier-met-de-paplepel-ingegoten $\sim a 3285103 /$. 
ing' taken in conditions of extreme violence? Future research that perhaps incorporates fieldwork or oral histories in Indonesia may see such photographs become objects of recognition, contestation, and mourning. What will it mean for Indonesians to look at photographs of themselves as part of a history of an independent nation born not just in anti-colonial but also in fratricidal violence? What will it mean for present-day Indonesians to see their ancestors and antecedents as perpetrators as well as victims of violence and, importantly, as occupants of the ambiguous categories between both ends of this spectrum? What of the women and children who worked for or with, as well as against, Dutch soldiers, sometimes to survive, perhaps also to prosper? What will be the ethics of looking at and reproducing these photographs, and who will they belong to?

In the three archives I have consulted, there are numerous examples of photographs that could constitute further, explicit evidence of atrocities committed during the military actions of the late 1940s, none of which I have reproduced here, as it would have been gratuitous to show that they existed even though they were not central to my analysis here. There are many amateur photographs that strongly suggest evidence for more cases of extreme violence perpetrated by Dutch soldiers against Indonesian combatants, as well as photographs that show atrocities committed against civilians, allegedly by local militias. ${ }^{67}$ Scope is therefore ample for future research into the cases of extreme violence that photographs might substantiate, if we look beyond content to the context in which it occurred.

Future research that analyses amateur photographs of atrocities, regardless of who they were committed by, will need to address the implications of bringing victims into pictures that were made by Dutch soldiers. A vast scholarship devoted to the ethics of spectatorship in disaster-including racialized, violent conflict and colonialist/nationalist wars-has demonstrated how reproducing and looking at photographs of victims can replicate the inequalities that produced their suffering in the first instance (Möller 1991; Sontag 2003; Sliwinski 2011). Importantly, this scholarship interrogates the functions of empathy

67 Photograph collections that strongly suggest the use of extreme violence by Dutch forces (and excluding those that have already been mentioned, which show the taking of Indonesian prisoners) are B. van Dijk BCO1O1, Berends BC40о, and Malta BC367; all at Image Bank WWII, NIOD, Amsterdam. There are also collections that suggest atrocities committed by Indonesian forces: A.F. van den Burgh A5740, K. van Wijk BC432, C.A.H. Roksnoer A56o6; all at Image Bank wWII, NIOD, Amsterdam; and the photographs taken during investigations following the Bersiap massacres in Album 216, Special Collections, Leiden University Library. Oostindie (2015:10, 29, 96-7) estimates from published sources alone that there were probably thousands of instances of atrocities, and similarly, on both sides. 
(whom does it serve, and for what purpose?) as a moral or emotional response to images of suffering (Zelizer 2010; Brown 2014:186-7). It attends to examining how photographs can enter the living communities of disaster victims and their descendants with dignity, in ways that enable critical dialogue among all 'stakeholders' about the impact of the past in the present and, importantly, how custodianship of violent histories might be shared between victims and perpetrators.

Rather than historians mainly working to unearth and reproduce further visual evidence of atrocity and expect it to 'speak for itself' to contemporary audiences and their juridically inflected expectations of what extreme violence might look like, approaches to using photographs must be considered that will enable Indonesian as well as Dutch viewers to speak to and with such findings in advance of their being made. This would seem a pressing concern given the current demands already placed on Indonesians, and historians of Indonesia, to acknowledge, assess, and reconcile genealogies and legacies of extreme violence in the post-independence period, most notably during the mass killings of 1965-1966 (McGregor 2012, 2013). The challenge, then, is for the colonial archive of Dutch soldiers' amateur photographs to be recast as a postcolonial archive that has a richer vein of meanings than 'proof' that both sides are tarnished with a history of violence.

Approaches to this postcolonial photographic archive will need to include consideration of the audiences for whom images are reproduced, in print or in 'live' showings, and decisions over when and whether it is necessary to show graphic images, particularly in the absence of careful analysis. I have deliberately not reproduced either published or archival images of atrocity, not only to problematize the 'accepted' (conventional, less visible) modes of violence in war that amateur soldiers' photographs routinely show but also out of respect for the dignity of murder victims whose stories I do not claim to tell here. In live showings, at seminars and conferences or public lectures, speakers might need to prepare for, invite, and incorporate responses from audience members who are invested in the topic because the subjects of the photographs (or indeed, the photographers) were members of their familial, social, or professional communities. Work done by scholars of photography, violence, and settler colonialism in other contexts is pertinent here. While there are important differences between settler-colonial histories and the nature of European imperialism in Indonesia—not least, that Indonesia was formally decolonized in a process that was mutually recognized (for the most part) by $1949^{68}$ -

68 Except for Dutch New Guinea, which remained in Dutch hands until 1962. 
it is worth reflecting on the opportunities for exploring how 'the important role of photographs in constituting Indigenous identity in the present, and the moral right of Indigenous people to have a say in their current use' has led to the development of 'cultural protocols surround[ing] the viewing of colonial imagery [that] have come to involve Indigenous control over representation' (Lydon 2016:xv). The crucial word for the Dutch-Indonesian context would be 'involve', 69 as both Dutch and Indonesian identities, commemorations, and histories will be implicated and contested in reassessments of the conflict of the late 1940s. It is not hard to imagine future situations in which photographs made by Dutch soldiers that show Indonesians might become meaningful to, and contested by, those communities. Such considerations recognize the continuing afterlives of colonial photographs that are reclaimed by postcolonial audiences, not just in the realm of historiography, through the interpretive efforts of historians, but also in the social communities in which such photographs are part of family and local histories too.

\section{5}

\section{Conclusions}

Dutch soldiers' amateur photographs from the Indonesian War of Independence are not simply illustrations of a history we can get from other sources, nor are they definitive evidence, retrieved from obscurity, of things we did not formerly know. The recent discourse around media reproductions of previously unknown execution photographs not only overlooks the existence of audiences and visual economies for these images at and after the time of their making; it also raises the question of where (and how) historians look for evidence of atrocity, and how we construct narratives about difficult pasts. Amateur photographs made by Dutch soldiers during the military actions of the late 1940s represent a contentious post/colonial archive whose uses will surely exceed their present purposes. Agents of the circulation of these images-historians, museums, the media-need to begin considering how the present-day communities that are linked to both the Dutch makers and the Indonesian and Dutch subjects of these photographs might respond to and (re)claim these images. These responses will extend the most recent, arguably narrow, function of such photographs in news media outlets, of affirming proof of acts of atrocity.

69 Rather than 'control', which arguably has greater pertinence for indigenous people in the settler-colonial contexts where decolonization is yet to occur. 
I have argued here that adopting the perspective of a public court of war crimes averts our eyes from a more complex, pervasive image of what constituted 'violence' and how it was justified, both during and after the Indonesian War of Independence. I have used Dutch soldiers' amateur photographs to propose some methods for reassessing how extreme violence was supported at the everyday level, and how photography enabled soldiers to make these structures visible or invisible for different audiences over time. The discovery of more explicit photographs alone, of the kind that demonstrate atrocity in modes that 'speak for themselves', will not settle questions of the extent, nature, and legacies of violence in this conflict, for the Netherlands or for Indonesia. Indeed, my contention has been that we are asking too much of a small number and narrow genre of photographs, and not enough of the larger archive of soldiers' amateur photographs, to extend historical understandings of this conflict. Dutch soldiers' amateur photographs reveal what these combatants considered within the realm of representation: to themselves, to their comrades in the armed forces (on active service and, later, as veterans), and to their social communities (first as correspondents on the distant 'home front', and later as people whom soldiers returned to and lived among). These questions of audience, and the visual economies that soldiers' photographs circulated within, illuminate the differentiated discussions about the war that were conducted in visual terms, between soldiers and veterans groups, and their friends and families-particularly regarding what was to be shared in the public sphere and what was for particular audiences. The traces of these patterned modes of distribution continue to shape what is recognized, accepted, and contested today.

The thousands of photographs that are already held in custodial institutions certainly constitute a rich archive, one that is significant not just because buried within it we might hope to find more long-lost evidence of atrocity, but because these sources illuminate in complex ways a shared history of violence that will entangle the Netherlands with Indonesia beyond the questions of war crimes and juridical restitution. This shared history has a complex genealogy, which can only be recovered if we take photographs, their makers, and their various audiences more fully into historical account.

\section{Acknowledgements}

Research for this article was funded by an Australian Research Council Discovery grant (DP170100948, 2017-19) and the Tholenaar van Raalte Fellowship in Photography at the Research Centre for Material Culture (2018). It was first 
presented as a paper at the 2016 ASEASUK Conference at soAs at the invitation of Alex Supartono, and as part of the panel 'The (Post)Colonial Archive: Re-imag(in)ing Southeast Asia'. It was refined as a public lecture for the KITLV Seminar Series in 2018. For their thought-provoking questions and feedback, I am grateful to all the participants at those two presentations, as well as the two anonymous reviewers for $B K I$. Thanks also to Timo de Jong for research assistance, and to René Kok and Harco Gijsbers at NIOD for great archival support.

\section{References}

Appadurai, Arjun (1986). 'Introduction: Commodities and the politics of value', in: Arjun Appadurai (ed.), The social life of things: Commodities in cultural perspective, pp. 3-63. Cambridge: Cambridge University Press.

Azoulay, Ariella (2011). The civil contract of photography. New York: Zone Books.

Azoulay, Ariella (2012). 'The execution portrait', in: Geoffrey Batchen, Mick Gidley, Nancy K. Miller, and Jay Prosser (eds), Picturing atrocity: Photography in crisis, pp. 249-6o. London: Reaktion Books.

Barthes, Roland (2010). Camera lucida: Reflections on photography. New York: Hill and Wang. [First published 1980.]

Berends, P.F. (1993). Tahoen jang soedah loepa: De vergeten jaren. Twentse jongens in Nederlands-Oostindië en Nieuw-Guinea 1942-1962. Haaksbergen: Hassink Drukkers.

Bijl, Paul (2014). 'Colonial memory and forgetting in the Netherlands and Indonesia', in: Bart Luttikhuis and Dirk Moses (eds), Colonial counterinsurgency and mass violence: The Dutch Empire in Indonesia, pp. 261-81. London and New York: Routledge.

Bijl, Paul (2015a). 'Saving the children? The Ethical Policy and photographs of colonial atrocity during the Aceh War', in: Susie Protschky (ed.), Photography, modernity and the governed in late-colonial Indonesia, pp. 103-32. Amsterdam: Amsterdam University Press.

Bijl, Paul (2015b). Emerging memory: Photographs of colonial atrocity in Dutch cultural remembrance. Amsterdam: Amsterdam University Press.

Blom, J. (1950). Awas, pijp-pijp datang! Gedenkboek 5-5-R.I. Deventer: n.p.

Brothers, Caroline (1997). War and photography: A cultural history. London and New York: Routledge.

Brouwer, A.M. (ed.) (1948). Tussen sawahs en bergen:Het levenvan de soldaat in de TïgerBrigade. Semarang: De Locomotief.

Brown, Kimberly Juanita (2014). 'Regarding the pain of the Other: Photography, famine, and the transference of affect', in: Elspeth H. Brown and Thy Phu (eds), Feeling photography, pp. 181-203. Durham and London: Duke University Press. 
Dreumel, Frans van (2008). 'Voorwoord', in: Bataljon ו- R.I. Leeuwarden: Uitgeverij Penn / Uitgeverij Elikser.

Edwards, Elizabeth (2001). Raw histories: Photographs, anthropology and museums. Oxford: Berg.

Fehrenbach, Heide (2016). 'Children and other civilians: Photography and the politics of humanitarian image-making', in: Heide Fehrenbach and Davide Rodogno (eds), Humanitarian photography: A history, pp. 165-99. Cambridge: Cambridge University Press.

Hagopian, Patrick (2006). 'Vietnam War photography as a locus of memory', in: Annette Kuhn and Kirsten Emiko McAllister (eds), Locating memory: Photographic acts, pp. 201-22. New York and Oxford: Berghahn.

Hirsch, Julia (1981). Family photographs: Content, meaning and effect. Oxford: Oxford University Press.

Hirsch, Marianne (1999). 'Introduction: Familial looking', in: Marianne Hirsch (ed.), The familial gaze, pp. xi-xxv. Hanover and London: University Press of New England.

Kennedy, Liam and Caitlin Patrick (2014). 'Introduction: The violence of the image', in: Liam Kennedy and Caitlin Patrick (eds), The violence of the image: Photography and international conflict, pp. 1-8. London and New York: I.B. Tauris.

Kok, René, Erik Somers and Louis Zweers (2015). Koloniale oorlog 1945-1949: Van Indië naar Indonesië. Amsterdam: Carrera.

Kreike, Emmanuel (2014). 'Genocide in the kampongs? Dutch nineteenth century colonial warfare in Aceh, Sumatra', in: Bart Luttikhuis and Dirk Moses (eds), Colonial counterinsurgency and mass violence: The Dutch Empire in Indonesia, pp. 45-63. London and New York: Routledge.

Langford, Martha (2001). Suspended conversations: The afterlife of memory in photographic albums. Montreal and Ithaca: McGill-Queen's University Press.

Langford, Martha (2006). 'Speaking the album: An application of the oral-photographic framework', in: Annette Kuhn and Kirsten Emiko McAllister (eds), Locating memory: Photographic acts, pp. 223-45. New York: Berghahn.

Limpach, Rémy (2016). De brandende kampongs van Generaal Spoor. Amsterdam: Boom.

Lorenz, Chris (2015). 'Can a criminal event in the past disappear in a garbage bin in the present? Dutch colonial memory and human rights: The case of Rawagedeh', in: Marek Tamm (ed.), Afterlife of events: Perspectives on mnemohistory, pp. 219-41. Basingstoke: Palgrave Macmillan.

Lowe, Paul (2014). 'The forensic turn: Bearing witness and the "thingness" of the photograph', in: Liam Kennedy and Caitlin Patrick (eds), The violence of the image: Photography and international conflict, pp. 211-34. London and New York: I.B. Tauris.

Luttikhuis, Bart (2014). 'Juridisch afgedwongen excuses: Rawagedeh, Zuid-Celebes en de Nederlandse terughoudendheid', BMGN-Low Countries Historical Review 1292:92-105. 
Luttikhuis, Bart (2018). 'Generating distrust through intelligence work: Psychological terror and the Dutch security services in Indonesia, 1945-1949', War in History 252:151-71.

Luttikhuis, Bart and Dirk Moses (2014). 'Introduction', in: Bart Luttikhuis and Dirk Moses (eds), Colonial counterinsurgency and mass violence: The Dutch Empire in Indonesia, pp. 1-24. London and New York: Routledge.

Lydon, Jane (2012). The flash of recognition: Photography and the emergence of Indigenous rights. Sydney: NewSouth Publishing.

Lydon, Jane (2016). Photography, humanitarianism, empire. London: Bloomsbury.

McGregor, Katherine (2012). 'Time, memory and historical justice: An introduction', Time \& Society 21-1:5-20.

McGregor, Katherine (2013). 'Memory studies and human rights in Indonesia', Asian Studies Review 37-3:350-61.

McGregor, Katherine (2014). 'From national sacrifice to compensation claims: Changing Indonesian representations of the Westerling massacres in South Sulawesi, 1946-47', in: Bart Luttikhuis and Dirk Moses (eds), Colonial counterinsurgency and mass violence: The Dutch Empire in Indonesia, pp. 282-307. London and New York: Routledge.

Meulen, G.J. van der (1947). 1 jaar X-Brigade. Surabaya: n.p.

Möller, Susan D. (1999). Compassion fatigue: How the media sell disease, famine, war and death. New York and London: Routledge.

Morton, Christopher and Elizabeth Edwards (2009). 'Introduction', in: Christopher Morton and Elizabeth Edwards (eds), Photography, anthropology and history: Expanding the frame, pp. 1-26. Burlington, VT: Ashgate.

Ooijen, Iris van and Ilse Raaijmakers (2014). 'Competitive or multidirectional memory? The interaction between postwar and postcolonial memory in the Netherlands', in: Bart Luttikhuis and Dirk Moses (eds), Colonial counterinsurgency and mass violence: The Dutch Empire in Indonesia, pp. 308-28. London and New York: Routledge.

Oostindie, Geert (2016). Serdadu Belanda di Indonesia 1945-1950: Kesaksian perang pada sisi sejarah yang salah. Jakarta: KITLV.

Oostindie, Geert, Irene Hoogenboom and Jonathan Verwey (2015). Soldaat in Indonesië 1945-1950: Getuigenis van een oorlog aan de verkeerde kantvan de geschiedenis. Amsterdam: Prometheus.

Pinney, Christopher (2003). 'Introduction: “How the other half ...”', in: Christopher Pinney and Nicolas Peterson (eds), Photography's other histories, pp.1-14. Durham and London: Duke University Press.

Poeze, Harry A. (2014). 'Walking the tightrope: Internal Indonesian conflict, 194549', in: Bart Luttikhuis and Dirk Moses (eds), Colonial counterinsurgency and mass violence: The Dutch Empire in Indonesia, pp. 176-97. London and New York: Routledge. 
Poole, Deborah (1997). Vision, race, and modernity: A visual economy of the Andean image world. Princeton, NJ: Princeton University Press.

Portielje, J.N.C. (ed.) (1949). Wij trokken naar Solo: Een verzameling van schetsen en herinneringen uit de troep tot en met de overdracht van Solo. Semarang: Van Dorp.

Prosser, Jay (2012). 'Introduction', in: Geoffrey Batchen, Mick Gidley, Nancy K. Miller, and Jay Prosser (eds), Picturing atrocity: Photography in crisis, pp. 7-14. London: Reaktion Books.

Protschky, Susie (2012). 'Tea cups, cameras and family life: Picturing domesticity in elite European and Javanese family photographs from the Netherlands Indies, c. 19001942', History of Photography 36-1:44-65.

Protschky, Susie (2014). 'Personal albums from early twentieth-century Indonesia', in: Gael Newton (ed.), Garden of the East: Photography in Indonesia 1850s-1940s, pp. 4855. Canberra: National Gallery of Australia.

Protschky, Susie (2018). 'Soldiers as humanitarians: Photographing war in Indonesia 1945-49', in: Jane Lydon (ed.), Visualising human rights, pp. 39-62. Perth: UwA Publishing.

Protschky, Susie (2019). Photographic subjects: Monarchy and visual culture in colonial Indonesia. Manchester: Manchester University Press. [Studies in Imperialism Series.]

Protschky, Susie (2020). 'Home at the front: Violence against Indonesian women and children in Dutch military barracks during the Indonesian National Revolution', in: Katherine McGregor, Ana Dragojlovic and Hannah Loney (eds), Gender, violence and power in Indonesia: Across time and space, pp. 59-83. London: Routledge. [Women in Asia Series.]

Roberts, Hilary (2012). 'War trophy photographs: Proof or pornography?', in: Geoffrey Batchen, Mick Gidley, Nancy K. Miller, and Jay Prosser (eds), Picturing atrocity: Photography in crisis, pp. 201-8. London: Reaktion Books.

Rose, Gillian (2010). Doing family photography: The domestic, the public and the politics of sentiment. Ashgate: Surrey.

Saptari, Ratna (2011). 'Domestic servants in colonial times', in: Susan Legêne and Janneke van Dijk (eds), The Netherlands East Indies at the Tropenmuseum: A colonial history, pp. 67-8o. Amsterdam: KIT Publishers.

Scagliola, Stef (2002). Last van de oorlog: De Nederlandse oorlogsmisdaden in Indonesië en hun verwerking. Amsterdam: Balans.

Scagliola, Stef (2014). 'Cleo's "unfinished business”: Coming to terms with Dutch war crimes in Indonesia's War of Independence', in: Bart Luttikhuis and Dirk Moses (eds), Colonial counterinsurgency and mass violence: The Dutch Empire in Indonesia, pp. 240-6o. London and New York: Routledge.

Schouten, J., T.J. Jansen Venneboer and H.A. Bijker (eds) (1997). 1947-1997 5-5-R.I. Doetinchem: WE DEO. 
Sliwinski, Sharon (2011). Human rights in camera. Chicago and London: The University of Chicago Press.

Smith, Shawn Michelle (2013). 'Afterimages: Abu Ghraib', in Shawn Michelle Smith: At the edge of sight: Photography and the unseen, pp. 195-212. Durham and London: Duke University Press.

Somers Heidhues, Mary (2014). 'Anti-Chinese violence in Java during the Indonesian revolution, 1945-49', in: Bart Luttikhuis and Dirk Moses (eds), Colonial counterinsurgency and mass violence: The Dutch Empire in Indonesia, pp. 155-75. London and New York: Routledge.

Sontag, Susan (2003). Regarding the pain of others. New York: Picador.

Struk, Janina (2011). Private pictures: Soldiers' inside view of war. London: I.B. Taurus.

Suski, Laura (2009). 'Children, suffering and the humanitarian appeal', in: Richard Ashby Wilson and Richard D. Brown (eds), Humanitarianism and suffering: The mobilization of empathy, pp. 202-22. Cambridge: Cambridge University Press.

Westerkamp, Pim (2012). 'Domestic life', in: Janneke van Dijk, Rob Jongmans, Anouk Mansfeld, Steven Vink and Pim Westerkamp, Photographs of the Netherlands East Indies at the Tropenmuseum, pp. 107-18. Amsterdam: KIT Publishers.

White, Benjamin (2004). 'Constructing child labour: Attitudes to juvenile work in Indonesia, 1900-200o', in: Rebecca Elmhirst and Ratna Saptari (eds), Labour in Southeast Asia: Local processes in a globalised world, pp. 77-106. London and New York: Routledge.

Wietsma, Annegriet (dir.) (2010). Tuan Papa. Amsterdam: Hellwig Products.

Wietsma, Annegriet, and Stef Scagliola (2013). Liefde in tijden van oorlog: Onze jongens en hun verzwegen kinderen in de Oost. Amsterdam: Boom.

Zelizer, Barbie (2010). About to die: Hownews images move the public. New York: Oxford University Press.

Zweers, Louis (2014). De gecensureerde oorlog: Militairen versus media in NederlandsIndië 1945-1949. Zutphen: Walburg Pers. 